Arch Biochem Biophys. 2010 November 1; 503(1): 41-53. doi:10.1016/j.abb.2010.05.027.

\title{
THE IMMUNE SYSTEM AND BONE
}

\author{
Roberto Pacifici, MD \\ Division of Endocrinology, Metabolism and Lipids, Department of Medicine, Emory University, \\ Atlanta, Georgia, and Immunology and Molecular Pathogenesis Program, Emory University, \\ Atlanta, GA
}

\section{Abstract}

$\mathrm{T}$ cells and $\mathrm{B}$ cells produce large amounts of cytokines which regulate bone resorption and bone formation. These factors play a critical role in the regulation of bone turnover in health and disease. In addition, immune cells of the bone marrow regulate bone homeostasis by cross-talking with bone marrow stromal cells and osteoblastic cells via cell surface molecules. These regulatory mechanisms are particularly relevant for postmenopausal osteoporosis and hyperparathyroidism, two common forms of bone loss caused primarily by an expansion of the osteoclastic pool only partially compensated by a stimulation of bone formation. This article describes the cytokines and immune factors that regulate bone cells, the immune cells relevant to bone, examines the connection between $\mathrm{T}$ cells and bone in health and disease, and reviews the evidence in favor of a link between $\mathrm{T}$ cells and the mechanism of action of estrogen and PTH in bone.

\section{Keywords}

T cells; B cells; TNF; estrogen; PTH; bone loss; osteoclasts; Wnt10b

\section{INTRODUCTION}

The close anatomical relationship between the bone marrow (BM) and bone has been recognized for centuries, but the existence of a functional relationship has emerged only recently. Critical steps include the discovery of the hemopoietic origin of osteoclasts (OCs), the capacity of hemopoietic cells to produce cytokine and growth factors essential for bone cell development. Moreover, BM stromal cells that are critical for the development of hemopoietic lines were found to have the capacity to differentiate into osteoblasts (OBs) and osteocytes. It has later become clear that the relationship is bidirectional as bone cells express surface molecules which are essential for the expansion of hemopoietic stem cells (HSCs) and their progeny. A relationship between the immune system and bone has long been suspected as bone loss is a constant feature of autoimmune and inflammatory conditions. The molecular links between the immune system and bone have emerged clearly only with the discovery of RANKL and its receptor RANK. These molecules were first identified as factors expressed on T cells and dendritic cells (DCs), respectively. RANKL and RANKL were shown to augment

(C) 2010 Elsevier Inc. All rights reserved.

Address correspondence to: Roberto Pacifici, M.D., Division of Endocrinology, Metabolism and Lipids, Emory University School of Medicine, 101 Woodruff Circle, Room 1309, Atlanta, GA 30322, Telephone: 404-712-8420, Fax: 404-727-1300,

roberto.pacifici@emory.edu.

Publisher's Disclaimer: This is a PDF file of an unedited manuscript that has been accepted for publication. As a service to our customers we are providing this early version of the manuscript. The manuscript will undergo copyediting, typesetting, and review of the resulting proof before it is published in its final citable form. Please note that during the production process errors may be discovered which could affect the content, and all legal disclaimers that apply to the journal pertain. 
the ability of DCs to stimulate naive T cell proliferation and enhance DC survival. They were later identified as the key osteoclastogenic molecules. It is now clear that a host of immune factors including costimulatory receptors, cytokines such as IFN $\gamma$ and TNF, and immune cells such as $\mathrm{T}$ and $\mathrm{B}$ lymphocytes play a fundamental role in the regulation of bone cell development and bone turnover, and in the pathogenesis of bone diseases.

This article focuses on cytokines relevant for the immune system and bone, and on the role of the immune system in the mechanism by which two essential calciotrophic hormones, estrogen and $\mathrm{PTH}$, regulate bone homeostasis in health and disease.

\section{CYTOKINES AND IMMUNE FACTORS THAT REGULATE BONE CELLS}

OCs arise by cytokine-driven proliferation and differentiation of monocyte precursors that circulate within the hematopoietic cell pool (1). This process is facilitated by BM stromal cells (SCs), which provide physical support for nascent OCs and produce soluble and membraneassociated factors essential for the proliferation and differentiation of OC precursors.

The minimal essential cytokines required for OC formation under basal conditions are RANKL and M-CSF. These factors are produced primarily by bone marrow SCs, OBs and activated T cells (2). RANKL is a TNF superfamily member which exists in membrane-bound and soluble forms. RANKL binds to the transmembrane receptor RANK expressed on the surface of OCs and OC precursors. RANKL also binds to osteoprotegerin (OPG), a soluble decoy receptor produced by numerous hematopoietic cells. Thus, OPG, by sequestering RANKL and preventing its binding to RANK, functions as a potent anti-osteoclastogenic cytokine (2). RANKL promotes the differentiation of OC precursors from an early stage of maturation into fully mature multinucleated OCs. RANKL is also capable of activating mature OCs, thus stimulating the capacity of these cells to resorb bone. M-CSF induces the proliferation of early OC precursors, the differentiation of more mature OCs, the fusion of mononucleated pre-OCs and increases the survival of mature OCs.

Although a RANKL-independent osteoclastogenic activity in T cell conditioned media was reported over a decade ago (3) only recently has the nature of the factor involved been elucidated. Using a biochemical purification strategy Weitzmann and Rifas (4) elucidated a novel cytokine named secreted osteoclastogenic factor of activated T cells (SOFAT), that when expressed recombinantly promotes the differentiation of OC precursors into bone resorbing OCs in a RANKL-independent manner. SOFAT was found to be derived from an unusual mRNA splice variant coded by the threonine synthase-like 2 gene homolog, and has no homology to any other known cytokine of cytokine family. The secretion of SOFAT by activated $\mathrm{T}$ cells may play an important role in inflammatory bone loss in conditions such as rheumatoid arthritis.

While RANKL and M-CSF are essential for physiologic OC renewal, additional cytokines, are responsible for the upregulation of $\mathrm{OC}$ formation observed in a variety of conditions such as inflammation and estrogen deficiency $(5,6)$. One such factor is TNF $\alpha$ (TNF), a cytokine that enhances OC formation by upregulating the SC production of RANKL and M-CSF $(7,8)$, and by augmenting the responsiveness of OC precursors to RANKL $(9,10)$. The ability of TNF to increase the osteoclastogenic activity of RANKL is due to synergistic interactions at the level of NFKB and AP-1 signaling (10). Another target of TNF is the RANKL receptor RANK, whose expression in OC precursors is synergistically upregulated by TNF and RANKL (11). TNF not only augments OC formation, but also stimulates OC activity (12) thus further driving an imbalance between bone formation and bone resorption. It should also be mentioned that TNF has been found to directly induces BMM differentiation into OCs in the absence of RANKL $(13,14)$, Another relevant effect of TNF is that of inhibiting osteoblastogenesis (15), thus blocking the expected homeostatic response of new bone formation. TNF impairs the 
function of bone-forming osteoblasts by suppressing mature osteoblast function such as the production of a matrix that is competent for mineralization and by blocking the differentiation of new osteoblasts from their progenitors (15).

The relevance of TNF in ovariectomy (ovx) induced bone loss has been demonstrated using multiple models. For example, ovx does not induce bone loss in TNF -/- mice and mice lacking the TNF receptor p55 (16), transgenic mice insensitive to TNF due to the overexpression of soluble TNF receptor (17) and mice treated with the TNF inhibitor TNF binding protein (18).

Like TNF, IL-1 promotes RANKL expression by BM SCs and OBs and stimulates OC lifespan and activity. IL-1 directly targets OC precursors and promotes OC differentiation in the presence of permissive levels of RANKL. Furthermore, IL-1 mediates, in part, the osteoclastogenic effect of TNF by enhancing SC expression of RANKL and by directly stimulating differentiation of OC precursors (19). TNF and IL-1 have potent anti-apoptotic effects in OCs prolonging OC lifespan and contributing toward accelerated bone resorption (20).

Another cytokine relevant for OC formation is IL-7 (21). IL-7 is a powerful lymphopoietic cytokine that has previously been recognized as a potent inducer of bone destruction in vivo (22). How IL-7 leads to bone loss is controversial, and it's mechanisms of action are only now beginning to be elucidated. IL-7 is a stimulator of both B and T cell lineages, and it has been suggested that IL-7 induces bone loss by a mechanism involving the expansion of cells of the B lineage, in particular B220 $\mathrm{IgM}^{-}$B cell precursors (22-25), as estrogen deficiency has been reported to potently induce the expansion of these cells $(22,25)$. How B lineage cells may lead to bone destruction is not presently understood but may involve overexpression of RANKL, a property of activated B cells (26). IL-7 is also established to regulate multiple stages of T cell metabolism (27). IL-7-/- mice are severely lymphopenic (28) and IL-7 receptor -/- mice have been reported to display increased bone volume and bone mineral density (22). In contrast, IL-7 transgenic mice have expanded BM cavities with focal osteolysis of cortical bone and eroded bone surfaces (29). This data suggests that IL-7 may induce bone loss by T cell and B cell mediated mechanisms. Indeed, IL-7 has been reported to induce production of RANKL by human T cells (30), and injection of IL-7 into mice in vivo induces bone destruction (22, 31 ) by eliciting the secretion by T cells of the key osteoclastogenic cytokines RANKL and TNF (31). In addition, levels of IL-7 are significantly elevated following ovx (32). Attesting to the key role of IL-7 in the bone destruction associated with estrogen deficiency, in vivo IL-7 blockade, using neutralizing antibodies, is effective in preventing ovx induced bone destruction (32). Furthermore, IL-7 induced osteoclastogenesis and bone loss is compounded by suppression of bone formation leading to uncoupling of bone formation from resorption.

An important, yet controversial, OC regulating factor is IFN $\gamma$. This factor was initially described as an anti-osteoclastogenic cytokine because is a potent inhibitor of osteoclastogenesis in vitro (33). The notion that IFN $\gamma$ is an inhibitor of bone resorption was reinforced by the finding that silencing of IFN $\gamma \mathrm{R}-/$ - signaling leads to a more rapid onset of collagen induced arthritis and bone resorption (34) as compared to WT controls, and by the report that IFN $\gamma$ decreases serum calcium and osteoclastic bone resorption in nude mice (35, $36)$.

However, observations in humans and in experimental models of disease indicate that IFN $\gamma$ promotes bone resorption and causes bone loss in a variety of conditions. Studies with IFN -/and IFNR -/- mice have revealed that among these conditions are estrogen deficiency and endotoxin-induced bone disease $(37,38)$. Mice lacking either IFN $\gamma$ production and/or IFN $\gamma \mathrm{R}$ expression are protected against ovx induced bone loss $(37,38)$, endotoxin-induced bone loss (37), and alveolar bone loss (39). Moreover, in erosive tubercoloid leprosy and psoriatic 
arthritis IFN $\gamma$ production correlates positively with tissue destruction (40,41). In addition, randomized controlled trials have shown that IFN $\gamma$ does not prevent bone loss in patients with RA $(42,43)$, nor the bone wasting effect of cyclosporin A (44). Furthermore, IFN $\gamma$ has been reported to be efficacious in the treatment of osteopetrosis through restoration of bone resorption, both in humans (45) and rodents (46). These latter findings conclusively demonstrate that in some conditions, including estrogen deficiency, the net effect of IFN $\gamma$ in vivo is that of stimulating osteoclastic bone resorption.

The complex effects of IFN $\gamma$ can be explained by the fact that IFN $\gamma$ influences OC formation both via direct and indirect effects (37). IFN $\gamma$ directly blocks OC formation through targeting of maturing OC. This effect is best observed in vitro $(33,47)$. However, IFN $\gamma$ is also a potent inducer of antigen presentation and thus of T cell activation. Therefore, when IFN $\gamma$ levels are increased in vivo, activated $\mathrm{T}$ cells secrete pro-osteoclastogenic factors and this activity offsets the anti-osteoclastogenic effect of IFN $\gamma$.

Another cytokine that has recently been linked to inhibition of OC formation is IL-23. Specifically this factor inhibits OC formation in the presence of $\mathrm{CD}^{+} \mathrm{T}$ cells (48), presumably inhibiting the activity of osteoclastogenic Th17 lymphocytes. The exact role of IL-23 remains to be established because IL-23 deficient mice do not have an increase number of OCs, although they have a reduced bone density (48) but while this appeared consistent with anti-osteolytic actions of IL-23, it was not accompanied by an elevated OC number.

In summary bone homeostasis is regulated by a large number of cytokines which exerts complex and overlapping effects on all bone cells. A complete understanding of their effects will require in vivo studies as often these factors induce different effects in vitro, due to the lack of a complete repertoire of target cells and interaction with other local factors.

\section{IMMUNE CELLS RELEVANT TO BONE}

\section{T cells}

T cells derive from HSCs that have initial lineage commitment in the BM migrate to the thymus where they complete their differentiation in naïve $\mathrm{T}$ cells. Mature naïve $\mathrm{T}$ cells are released by the thymus into the systemic circulation and home to all secondary lymphoid organs including the BM. T cells express either an $\alpha \beta$ or $\gamma \delta$ T cell receptor (TCR) on the cell surface, and these receptors are responsible for recognizing a diverse range of antigens (49). Most $\mathrm{T}$ lymphocytes are $\alpha \beta$ T cells, a lineage which express either the CD4 or CD8 marker. By contrast, the majority of $\gamma \delta \mathrm{T}$ cells lack expression of CD4 and CD8 and their function remains largely unknown (49). Another small subset of T cells ( $<1 \%$ total T cells in the mouse) is known as natural killer T (NKT) cells, which can be defined based on the expression of both the NK marker NK1.1 and the $\alpha \beta$ TCR (50). Although small in number, NKT cells can produce large amounts of cytokines, and have been implicated in a variety of immune responses including autoimmunity, graft rejection, and responses to pathogens (50). CD4+ T cells can also be subdivided based on the types of cytokines produced and broadly grouped into the Th1 (IFN $\gamma$ ), Th2 (IL-4), and Th17 (IL-17) subsets. Of these, Th17 T cells have been suggested to be the osteoclastogenic T cells. Th17 link T cell activation and bone resorption through a dual mechanism. Firstly, they produce high levels of RANKL. Secondly, they produce IL-17 (51), a cytokine which induces RANKL expression in SCs and OBs (52). Another type of CD4 positive $\mathrm{T}$ cell can be defined based on expression of CD25 and the transcription factor FoxP3. These cells are known as regulatory $\mathrm{T}$ cells (Tregs), and are critical in the prevention of autoimmune disease. Importantly, estrogen upregulates the expression of FoxP3 and potentiates the regulatory activity of Tregs (53). 
Both in humans and mice the BM hosts fully functional mature T cells $(\sim 5-8 \%$ of the total mononuclear BM cells) (54). The BM serves as a site for the initiation of naïve $\mathrm{T}$ cells responses $(55,56)$ and as a reservoir of CD8 memory T cells $(54)$. T cells play a pivotal role in the bone loss associated with inflammatory arthritis (57), periodontal bone disease (58) and ovariectomy (ovx) (59-61). T cells have the capacity to secrete a wide repertoire of cytokines, some proosteoclastogenic and some anti-osteoclastogenic. $\mathrm{CD} 8^{+} \mathrm{T}$ cell have been reported to be anti-steoclastogenic in vitro (62) while regulatory T cells inhibit OC differentiation (63), and correlate negatively with T cell expression of RANKL in the bone resorptive lesions in periodontitis (64). It has further been reported that depletion of $\mathrm{CD}^{+}$and $\mathrm{CD} 8^{+} \mathrm{T}$ lymphocyte subsets in mice in vivo enhances vitamin $\mathrm{D} 3$-stimulated $\mathrm{OC}$ formation in vitro by a mechanism involving increased prostaglandin E production (65).

Activated T cells have also been suggested to inhibit osteoclastogenesis by diverting early OC precursors towards DC differentiation (66). Indeed T cells have the capacity to generate both osteoclastogenic cytokines such as RANKL $(3,67)$ and TNF, as well as anti-osteoclastogenic factors such as IL-4. It has also been suggested that the effects of activated T cells on osteoclastogenesis in vitro depends on the manner in which they are activated (68). The net effect of $\mathrm{T}$ cells on $\mathrm{OC}$ formation may consequently represent the prevailing balance of antiand pro-osteoclastogenic $\mathrm{T}$ cell cytokine secretion. However it appears that during stimulated conditions such as inflammation (57) and during estrogen deficiency $(9,16,32,38)$ proosteoclastogenic cytokines prevail.

Little is known about the anti-osteoclastogenic activities of $\mathrm{T}$ cells in vivo, however although BMD is normal or elevated in very young T cell deficient nude mice (9), BMD decreases significantly as the mice age (37) suggesting that $\mathrm{T}$ cells may play a protective role in postembryonic basal bone modeling. Recently, we performed a detailed characterization of the bone phenotype of nude mice, confirming an osteopenic phenotype by extensive DXA and micro-CT analyses (69). Histological analyses and metabolic markers of bone turnover revealed that this osteopenia was a consequence of increased osteoclastic bone resorption (69). As physiological bone turnover is regulated principally by the ratio of RANKL to OPG in the bone microenvironment we quantitated mRNA for RANKL and OPG in nude mice and wild type controls. These data revealed a significant deficit in OPG mRNA in the BM of nude mice (69). Surprisingly, this deficit in OPG production was largely accounted for by a significant reduction in OPG production by B cells. As further discussed below, this is because engagement of the $\mathrm{B}$ cell receptor $\mathrm{CD} 40$ by the $\mathrm{T}$ cell surface molecule $\mathrm{CD} 40 \mathrm{~L}$ promotes $\mathrm{B}$ cell OPG production (69).

In summary it is now clear that all the major subsets of $\mathrm{T}$ cells play important regulatory effects in bone in health and in disease.

\section{B cells}

$\mathrm{B}$ cells represent an abundant population of the BM which is recognized for their capacity to produce antibodies, and for their role as professional antigen presenting cells. However, B cells have recently been directly implicated in the regulation of bone resorption as they represent a major source of OPG. Historically, an extensive in vitro data set has led to the widely accepted precept that the major source of BM OPG is the OB and/or its immediate precursor, the BM SC $(70,71)$. More recent data have show that $B$ cells are more likely the dominant producers of OPG in the bone microenvironment in vivo (69). This conclusion was arrived at following an extensive series of investigations into the bone phenotype of B cell knockout (KO) ( $\mu \mathrm{MT} /$ $\mu \mathrm{MT}$ ) mice (69). B cell KO mice present at baseline with an osteoporotic phenotype (72), a consequence of enhanced osteoclastic bone resorption. Examination of the RANKL/OPG ratio in $\mathrm{B}$ cell $\mathrm{KO}$ bone marrow identified a specific deficiency in OPG mRNA and in protein expression (69). Reconstitution of young B cell KO mice with B cells by means of adoptive 
transfer, completely rescued mice from development of osteoporosis, by normalizing OPG production (69).

Interestingly, it has previously been reported that B cell OPG production by human tonsil derived B cells could be significantly upregulated by the activation of CD40 signaling by an activating antibody (73). CD40 is a costimulatory molecule constitutively expressed by professional antigen presenting cells (APCs) and partners with a receptor that is transiently upregulated on the surface of activated T cells. In agreement with the studies of Yun et. al. \{Yun, 1998 \#101\}, we found that mouse splenic B cells likewise produced upregulated concentrations of OPG in response to a recombinant soluble ligand to CD40 (sCD40L) (69). In line with these data both CD40 and CD40L KO mice displayed an osteoporotic phenotype and a significant deficiency in BM OPG concentrations (72).

Thus the emerging data suggests that the B lineage, rather than the osteoblast lineage, is likely the major source of OPG in the bone microenvironment and that $\mathrm{T}$ cell signaling to $\mathrm{B}$ cells, through the costimulatory molecules $\mathrm{CD} 40 \mathrm{~L}$ and $\mathrm{CD} 40$ play an important role in regulating basal OC formation and in regulating bone homeostasis. Recent preliminary studies by O'Brien et. al., using an elegant transgenic mouse model in which osteoblasts and their immediate progenitors were specifically ablated further supports the contention that osteoblasts are not the dominant source of OPG in bone, as OPG transcript levels and OC number remained unaffected following OB ablation (74).

These findings may provide in part a novel explanation for the propensity for osteopenia and osteoporosis development in numerous pathological conditions in which altered immune function or immunodeficiency in B cells and/or T cells results. Such conditions include HIV infection, solid organ and bone marrow transplantation, multiple myeloma in which normal B cells are significantly depleted, ageing, and patients treated with immunosuppressive agents such as glucocorticoids.

\section{Antigen presenting cells}

$\mathrm{T}$ cell activation is induced by the presentation of antigens to $\mathrm{T}$ cells by antigen presenting cells (APCs). These cells internalize and digest antigenic peptide and export to the cell surface antigen fragments for presentation to $\mathrm{T}$ cells. The antigenic peptides are bound to major histocompatibility complex (MHC) molecules, and are presented to the T cell receptor (TCR). APCs expressing class II MHC molecule activates CD4+ T cells, while APCs expressing class I MHC molecule activates CD8+ T cells. APCs also express multiple costimulatory molecules which, which in concert with antigen loaded MHCs, are require to induce $\mathrm{T}$ cell activation. APCs are divided in professional and non-professional APCs, depending on whether they express MHC molecule constitutively or only under stimulated conditions. Professional APCs include DCs, B cells and macrophages. As discussed below, APCs are relevant to bone homeostasis primarily because estrogen prevents $\mathrm{T}$ cell activation and $\mathrm{T}$ cell dependent bone loss by blocking antigen presentation $(38,75-77)$.

\section{ROLE OF T CELLS IN THE MECHANISM OF ACTION OF PTH IN BONE}

\section{Effects of PTH on bone}

PTH plays a critical regulatory role in calcium metabolism. Secreted in response to small decrements in serum ionized calcium, this hormone defends against hypocalcemia, in part by stimulating bone resorption and thereby the release of calcium from the skeleton. In addition to its role in regulating the level of serum calcium, sustained overproduction, or in vivo continuous infusion of PTH (cPTH), is a cause of bone disease. Secondary hyperparathyroidism has been implicated in the pathogenesis of senile osteoporosis (78), and primary hyperparathyroidism, is associated with accelerated bone loss (79) and osteopenia 
(80). However, when injected daily in humans and animals at low dose, a regimen known as intermittent PTH (iPTH) treatment, the hormone stimulates trabecular and cortical bone formation, leading to marked increases in bone volume and strength. Attesting to potency, iPTH, has been shown to decrease the risk of fractures in humans, and is an FDA approved treatment modality for postmenopausal women and men with osteoporosis $(81,82)$.

PTH exerts its anabolic activity by binding to the PPR receptor (also known as PTH-1R), a G protein coupled receptor expressed on OBs, osteocytes and SCs $(83,84)$. Ligand binding to PPR activates the cyclic AMP-dependent protein kinase A, and calcium-dependent protein kinase $\mathrm{C}$ signaling pathways. Mice in which the PPR has been ablated by homologous recombination have decreased trabecular bone and increased thickness of cortical bone during fetal development (85). Conversely, osteoblastic expression of the constitutively active PPR increases osteoblastic function in the trabecular and endosteal compartments, and decreases OB activity in the periosteum (83). The net effect of these actions is a substantial increase in trabecular bone volume and a decrease in cortical bone thickness of the long bones (83). Transgenic mice expressing a constitutively active PTH receptor exclusively in osteocytes also exhibit increased bone mass and bone remodeling, as well as reduced expression of the osteocyte-derived Wnt antagonist sclerostin, increased Wnt signaling, increased OC and OB number, and decreased OB apoptosis (86). PTH receptor signaling in osteocytes has been shown to increase bone mass and the rate of bone remodeling through LRP5 dependent and independent mechanisms, respectively (86).

PTH promotes bone formation by increasing the number of OBs (87-89) through multiple effects, including activation of quiescent lining cells $(90)$, increased OB proliferation $(91,92)$ and differentiation (91,93), attenuation of pre-OB and OB apoptosis (94-97), and signaling in osteocytes (86). However, the specific contribution of each of these effects to the overall anabolic activity of PTH remains controversial. In addition, PPR signaling stimulates the release of growth factors including IGF-1 (82), TGF $\beta$ (98), and FGF-2 (99) which stimulate the proliferation, differentiation and survival of OBs $(82,100)$.

PTH signaling has been observed to intersect Wnt pathways in OBs. Wnts are secreted signaling proteins which influence diverse developmental processes (101). Activation of Wnt signaling induces OB proliferation (102) and differentiation $(100,103)$, prevents pre-OB and OB apoptosis $(96,97,104)$, and augments OB production of OPG (105). Wnt proteins initiate a canonical signaling cascade by binding to receptors of the Frizzled family together with coreceptors, members of the low-density lipoprotein receptor-related protein (LRP) family, LRP5 and LRP6, which results in the stabilization of cytosolic $\beta$-catenin. Recently a new member of this family LRP4, has been discovered on OBs and implicated in the mechanism of action of PTH (106). Lrp4 is expressed in bone and cultured osteoblasts and binds Dkk1 and sclerostin in vitro (106). A nuclear complex of beta-catenin and the T-cell factor/lymphoid enhancer factor (TCF/LEF) family of transcription factors then interacts with DNA to regulate the transcription of Wnt target genes (107). Wnt proteins also signal through non-canonical pathways which involve the Src/ERK and Pi3K/Akt cascades (96).

PTH is a canonical Wnt signaling agonist which increases $\beta$ catenin levels in osteoblastic cells $(97,108)$ an effect which occurs through modulation of both the protein kinase A and protein kinase C pathways (97). PTH, once bound to PPR, is also capable of forming a complex with LRP6 which results in LRP6 signaling and $\beta$ catenin activation (109). Thus, PTH activates Wnt signaling in osteoblastic cells through both Wnt ligands dependent and Wnt ligands independent mechanisms. Moreover, PTH down regulates the production of sclerostin, an osteocyte derived Wnt antagonist which acts by binding to LRP5 and LRP6 $(110,111)$, Dickkopf-1, a soluble LRP5 and LRP6 signaling inhibitor (108), and Sfrp-4, a factor which binds Wnt proteins thus antagonizing both canonical and non-canonical Wnt signaling (112). 
The relevance of sclerostin in the mechanism of action of PTH remains uncertain because studies with sclerostin transgenics and sclerostin KO mice have not provided conclusive evidence that this osteocytic peptide is the key target of PTH $(113,114)$.

Uncertainty remains with regard to the identity and the source of Wnt ligands which activate Wnt signaling in response to PTH treatment are not completely understood.

Recently, PTH signaling has also been observed to intersect TGF $\beta$ signaling in OBs. In fact the TGF $\beta$ type II receptor binds to the PTH receptor PPR, phosphorylates its intracellular tail, and promotes its internalization, thus limiting the effects of PTH on OBs (115). As a result, mice with a conditional deletion of TGF $\beta$ type II receptor in OBs have high trabecular bone mass (115). The interaction between PTH and TGF $\beta$ receptors could provide a means to integrate local and systemic bone signals.

\section{T cells and PTH induced bone loss}

T lymphocytes, expresses functional PPR (Figure 1), responds to PTH $(116,117)$, and stimulates OB differentiation (118-120). Yet a role for T cells in the mechanism of action of PTH has remained undetected for a long period of time in part because transplantation of tumors producing PTH and/or PTHrP in nude mice is known to cause hypercalcemia and increased bone resorption in spite of the absence of T cells in the host (121-123). Hory et al (124), were the first to report that transplantation of human parathyroid gland fragments from patients with primary and secondary hyperparathyroidism into nude mice fails to stimulate OC formation and bone resorption. The apparent discrepancy between these reports is explained by the higher levels of circulating PTH/PTHrP attained by transplanting PTH/PTHrP producing tumors, as compared to those obtained by transplanting hyperplastic parathyroid tissues.

These observations prompted more in depth investigations on the role of $\mathrm{T}$ cells as mediators of the pro-resorptive effect of cPTH treatment. We found that an infusion of cPTH that mimics hyperparathyroidism fails to induce $\mathrm{OC}$ formation, bone resorption and cortical bone loss in mice lacking $\mathrm{T}$ cells (125). By contrast, $\mathrm{cPTH}$ equally stimulated bone formation in $\mathrm{T}$ cell replete and T cell deficient mice. Moreover, these studies revealed the existence of a cross-talk between T cells and BM SCs mediated by the CD40L/CD40 signaling system. T cells provide proliferative and survival cues to SCs and sensitize SCs to PTH through CD40L, a surface molecule of activated $\mathrm{T}$ cells that induces CD40 signaling in SCs. As a result, mice lacking T cells or T cell expressed CD40L have a lower number of SCs. Furthermore, these SCs differ from WT SCs as they produce lower amount of RANKL and do not decrease their production of OPG in response to PTH. Therefore, SCs from T cell deficient mice have a lower capacity to support $\mathrm{OC}$ formation in vivo and in vitro. The alteration in $\mathrm{SC}$ function is the ultimate reason why deletion of $\mathrm{T}$ cells or $\mathrm{T}$ cell expressed $\mathrm{CD} 40 \mathrm{~L}$ blunts the bone catabolic activity of PTH (125). (Figure 2)

In spite of a smaller SC pool and a blunted SC osteoclastogenic activity, $\mathrm{T}$ cell deficient mice possess a normal anabolic response to $\mathrm{cPTH}$. This may suggest that the $\mathrm{SCs}$ which produce osteoclastogenic factors and support $\mathrm{OC}$ formation are not the same cells that differentiate into OBs, the cells that form osteoid and mineralize it, a hypothesis recently proposed by O'Brien et al (74). Indeed osteoclastogenic SCs express intercellular adhesion molecule-1 (ICAM-1) which is necessary for binding to OC precursors (126), while matrix producing osteoblastic cells are ICAM-1 negative (127). However, it is also possible that a defective stimulation of bone formation might emerge in T cell deficient mice in response to long-term cPTH treatment.

Cortical bone represents about $80 \%$ of the entire skeletal mass (128) and cortical volume and thickness are major predictors of bone strength and fracture risk (129). Thus, the T cell 
dependent bone effects of PTH are relevant for the risk of long bone fractures associated with primary and secondary hyperparathyroidism $(78-80,130)$.

PTH does not increase antigen presentation and $\mathrm{T}$ cell activation. However, it is likely that baseline Ag presentation, which leads to spontaneous activation of $\mathrm{T}$ cells in the $\mathrm{BM}$, may be required for PTH to induce its catabolic effect. Indeed the BM contains a relative large number of memory T cells which have increased reactivity to self peptides and foreign $\mathrm{Ag}$ (131). T cell activation requires the interaction of the costimulatory molecules on APCs with the T cell expressed counter receptors such as CD28 and CD40L. A pharmacological approach to test the role of costimulation is provided by Abatacept, a mAb approved for the treatment of Rheumatoid Arthritis which blocks $\mathrm{T}$ cell costimulation and induces $\mathrm{T}$ cell anergy and apoptosis $(132,133)$. We found that PTH induced bone loss is prevented using this inhibitor of costimulation (figure 3). In the same study we found that arrest of Ag presentation through silencing of class I and class II MHC-TCR interactions prevents the capacity of cPTH to induce cortical bone loss. In summary, these findings provide further evidence of a novel regulatory link between the immune system and the mechanism of action of PTH.

\section{Role of T cells in the anabolic activity of intermittent PTH treatment}

The hypothesis that $\mathrm{T}$ cells may play a role in the anabolic response to iPTH was first proposed by Pettway et al (134), who investigated the effects of daily injections of PTH for up to 7 weeks on the growth of ectopic "ossicles" implanted in nude mice. This investigation disclosed that iPTH increased the bone content of the implanted WT ossicles, a structure which contains normal BM, but failed to induce vertebral bone growth in host nude mice (134).

These observations prompted us to investigate whether $\mathrm{T}$ cells contribute to the anabolic response to iPTH. Studies conducted in four strains of T cell deficient mice (TCR $\beta$-/-, RAG2 $-/-$, class I and II MHC double KO mice, and nude mice) revealed that mice lacking T cells, exhibit a blunted increase in bone formation and trabecular bone volume in response to iPTH (135). Furthermore, adoptive transfer of $\mathrm{T}$ cells into $\mathrm{T}$ cell deficient mice restored a normal response to $\mathrm{iPTH}$.

The effects of iPTH on bone volume and the indices of bone strength measurable by $\mu \mathrm{CT}$ are blunted but not abolished in the absence of T cells. By contrast, direct measurements of bone strength by 4-point bending revealed that the capacity of iPTH to improve bone strength is completed dependent on the presence of T cells. Although the reason for this discrepancy is unknown, is possible that $\mathrm{T}$ cells might be required to improve the material property of bone. It should also be noted that while the stimulation of bone formation induced by iPTH was severely blunted in $\mathrm{T}$ cell deficient mice, $\mathrm{T}$ cells did not improve the capacity of $\mathrm{cPTH}$ to stimulate bone formation. The reason for this critical difference remains to be determined.

$\mathrm{T}$ cells were found to augment the capacity of iPTH to improve architecture in trabecular but not in cortical bone. Although the reason of this selectivity is unknown, a lack of access of $\mathrm{T}$ cells to cortical surfaces is not a likely explanation, as T cells reach endosteal and periosteal bone surface through blood vessels and recirculate in and out of the BM (136).

With regard of the mechanism by which T cells potentiate the bone anabolic activity of $\mathrm{iPTH}$, our studies have disclosed that PTH stimulates BM CD8+ T cells to produce large amounts of Wnt10b (135), a Wnt protein which activates Wnt signaling in SCs and OBs, thus increasing OB differentiation and life-span (Figure 4). iPTH also caused a small increase in the production of Wnt10b by BM CD4+ cells which was associated with a slightly diminished anabolic response in class II MHC -/- mice, suggesting that production of Wnt10b by CD4+ cells contributes, in small part, to the anabolic activity of iPTH. The relevance of CD8+ cells was demonstrated by the inability of iPTH to promote bone anabolism in class I MHC -/- mice 
(135), while the pivotal role of $\mathrm{T}$ cell produced Wnt10b was revealed by the hampered effect of iPTH on BV/TV and bone turnover in TCR $\beta$-/- mice reconstituted with T cells from Wnt $10 \mathrm{~b}$ -/- mice. It is likely that iPTH directly targets CD8+ T cells and stimulates their production of Wnt10b. This hypothesis is supported by the strong expression of PPR in CD8+ T cells, and the capacity of in vitro PTH treatment to promote cAMP production and Wnt10b expression in CD8+ murine and human lymphocytes.

While in vitro PTH treatment increased Wnt10b mRNA expression in splenic T cells, iPTH upregulated Wnt $10 \mathrm{~b}$ production only by BM T cells. This diversity might be explained by the different dose and time of exposure to PTH. However, since adoptive transfer of spleen T cells into TCR $\beta$-/- mice was followed by a restoration of a full responsiveness to iPTH, the data suggest that the capacity of $\mathrm{T}$ cells to upregulate their production of $\mathrm{Wnt} 10 \mathrm{~b}$ in response to iPTH is not an intrinsic feature of T cells, but rather is induced by environmental cues.

Osteoblastic cells produce several bone anabolic Wnt ligands including Wnt10b, Wnt7a and Wnt3b $(137,138)$. Thus, it could be argued that $T$ cells may release additional factors which regulate OBs in addition to Wnt10b. Extensive studied from our laboratory have disclosed that iPTH does not increase the production of Wnt proteins other than Wnt10b (although iPTH slightly increase the mRNA levels of Wnt7b and Wnt3a it does not upregulate the protein levels of these factors). Analysis of the effects of iPTH on the T cell production of cytokines known to regulate OB function has disclosed that iPTH has no effects on the production of IL-1, IL-4, IL-6, IL-7, and TGF $\beta$ However, iPTH has a slightly stimulatory effect on the production of TNF.

The anabolic activity of iPTH is not identical in all strains of T cell deficient mice. In fact, while some strains had no increase in bone volume in response to PTH, other exhibited a blunted but not a completely absent response. The magnitude of the anabolic response to iPTH in T cell null mice may be related to a strain and age dependent capacity of iPTH to inhibit the bone cells production of Wnt inhibitors such as sclerostin, (110,111), Dickkopf-1 (108) and Sfrp- 4 (112). These factors have been shown to contribute to the anabolic activity of iPTH through T cell independent mechanisms. Since B cells are regulated by PTH (139), the response of RAG2 -/- mice to iPTH might also have been determined by the lack of B cells which is a feature of Rag2 -/- mice.

The enhancement of bone formation induced by iPTH is accompanied by a stimulation of bone resorption which is driven by increased production of RANKL and decreased release of OPG in the bone microenvironment (140). The direct effects of PTH on RANKL/OPG production are mitigated, in part, by the iPTH induced activation of $\beta$ catenin in OBs, as this transcriptional regulator stimulates their production of OPG (105) and represses that of RANKL (141). The latter is one of the mechanisms which prevent bone resorption from offsetting the anabolic activity of iPTH.

Osteoblastic cells from WT mice treated with iPTH in vivo exhibited increased commitment to the osteoblastic lineage, proliferation, differentiation and life span in vitro, as compared to the corresponding cells from $\mathrm{T}$ cell deficient mice. Thus, $\mathrm{T}$ cells, like PTH, affect all aspects of OB life cycle. Remarkably, these differences were demonstrated in OBs purified from BM cultured for 7 days without the addition of PTH, suggesting that in vivo the hormone regulates early commitment steps of SCs and their osteoblastic progeny through T cell produced Wnt10b, and that these steps are not reversed by the absence of PTH and T cells in vitro. This model is consistent with the capacity of Wnt signaling to guide cell fate determination (101). A similar paradigm has been described in ovariectomized mice, a model where estrogen withdrawal in vivo leads to the formation of SCs which exhibit an increased osteoclastogenic activity which persists in vitro for 4 weeks (142). 
In summary, $\mathrm{T}$ cell mediated activation of Wnt signaling in osteoblastic cells plays a key permissive role in the mechanism by which iPTH increases bone strength, suggesting that $\mathrm{T}$ cell osteoblast cross-talk pathways may provide pharmacological targets for bone anabolism.

\section{T CELLS AND BONE LOSS INDUCED BY MENOPAUSE}

\section{T cells and ovariectomy induced bone loss}

The decline of ovarian function at menopause results in decreased production of estrogen and a parallel increase in FSH levels. The combined effects of estrogen deprivation and raising FSH production cause a marked stimulation of bone resorption (143) and a period of rapid bone loss which is central for the onset of postmenopausal osteoporosis (128). In mice the acute effects of estrogen deprivation and FSH elevation are modeled by ovariectomy (ovx) which, like natural menopause in humans, stimulates bone resorption by increasing $\mathrm{OC}$ formation $(59,144,145)$ and lifespan $(146-148)$. The net bone loss caused by ovx is limited, in part, by an increase in bone formation resulting from stimulated osteoblastogenesis (149). This compensation is fueled by an expansion of the pool of BM SCs, increased commitment of such pluripotent precursors toward the osteoblastic lineage (149), and enhanced proliferation of early OB precursors (150). The capacity of estrogen deficiency to stimulate OB apoptosis $(151,152)$ and to extend OC lifespan (146-148) is the likely reason why after ovx bone formation does not increase as much as resorption.

The stimulatory effect of ovx on SCs is equally relevant for osteoclastogenesis as one of the consequences of estrogen deprivation is the formation of osteoblastic cells with an increased osteoclastogenic activity (142), that is the capacity to support OC formation.

It is well established that estrogen withdrawal leads to distinct forms of bone loss $(153,154)$. The first is a rapid loss of trabecular and cortical bone due to stimulation of bone resorption which occurs in the first 2-4 weeks after ovx, driven by increased osteoclastogenesis and decreased OC apoptosis $(59,145)$. This phase is followed by a slower but more prolonged loss of mainly cortical bone due to incomplete refilling of the resorption cavities due to insufficient OB activity and lifespan (145). An expansion of the osteoclastic pool is therefore the key mechanism responsible for the bone loss which occurs early after ovx. One cytokine responsible for augmented osteoclastogenesis during estrogen deficiency is TNF, and its relevance has been demonstrated in multiple animal models. For example, ovariectomy (ovx) fails to induce bone loss in TNF knockout mice and in mice lacking the p55 TNF receptor (16). Likewise transgenic mice insensitive to TNF due to the overexpression of a soluble TNF receptor (17), and mice treated with the TNF inhibitor TNF binding protein (18) are protected from ovx induced bone loss. The presence of increased levels of TNF in the BM of ovx animals and in the conditioned media of peripheral blood cells of postmenopausal women is well documented (155-157).

Activated T cells are a major source of TNF and evidence has accumulated that ovx increases the levels of TNF in the BM primarily by increasing T cell TNF production. Attesting to the relevance of $\mathrm{T}$ cells in estrogen deficiency induced bone loss in vivo, are reports from our laboratory that ovx fails to induce trabecular and cortical bone loss in nude mice $(9,16,37$, 158) and in WT mice treated with Abatacept (77) (Figure 5). The specific relevance of T cell TNF production in vivo was demonstrated by the finding that while reconstitution of nude recipient mice with T cells from wild type (WT) mice restores the capacity of ovx to induce bone loss, reconstitution with T cells from TNF deficient mice does not (16).

An independent confirmation of the role of T cells in ovx induced bone loss was provided by Yamaza et al who reported that ovx fails to induce bone loss in nude mice and in WT mice in 
which $\mathrm{T}$ cell activation was blocked by aspirin (61). Studies have also shown that menopause increases $\mathrm{T}$ cell activations and T cell production of TNF and RANKL in humans (159).

By contrast, Lee et al (160) showed that nude mice are protected against the loss of cortical, but not trabecular bone induced by ovx. In the same study other strains of T cell, and T and B cell deficient mice were found to lose either trabecular or cortical bone after ovx (160). The discrepancy between these conflicting studies is likely explained by differences in the experimental design, the lack of B cells in some models, and compensation mechanisms. For example, our $\mu \mathrm{CT}$ analysis of the effects of ovx in nude mice was conducted in mature 16 weeks old animals (158). In the same investigation prospective in vivo measurements of BMD were obtained by DXA (158). Lee et al (160) conducted their $\mu \mathrm{CT}$ analysis in 5-6 week old mice, an age when in most strains ovx blunts trabecular bone formation (161-164).

Accordingly, they found ovx to decrease static histomorphometric indices of bone formation in nude mice and to increase bone formation in WT controls (160). They also found ovx not to increase two sensitive indices of bone resorption in both WT and nude mice (160). These findings raise the possibility that the main effect of ovx in very young $\mathrm{T}$ cell deficient mice is that of blunting bone formation rather than increasing bone resorption, leading ovx to cause an arrest in skeletal growth, rather than bone loss. Prospective in vivo measurements of bone density and analysis of dynamic histomorphometric indices of bone formation in mature mice will be required to reconcile our studies with those of Lee at al (160).

In summary, upregulated $\mathrm{T}$ cell production of TNF appears to be a key mechanism by which ovx induces bone loss because ovx increases T cell TNF production in the BM and secondary lymphoid organs; TNF increases the responsiveness of OC precursors to RANKL, mice lacking or insensitive to TNF are completely protected against ovx-induced bone loss; and WT T cell reconstitution in nude mice restores the capacity of ovx to induce bone loss while reconstitution of nude mice with TNF -/- T cells fails to do so.

\section{Mechanisms of estrogen regulation of T cell TNF production}

Ovariectomy upregulates T cell TNF production primarily by increasing the number of TNF producing T cells (16). This is the result of a complex pathway which involves the thymus and the bone marrow. In the BM, ovx promotes $\mathrm{T}$ cell activation, resulting in increased $\mathrm{T}$ cell proliferation and life span through antigen presentation by macrophages and dendritic cells (DC) $(38,165)$. This process is due to the ability of estrogen deficiency to upregulate the expression of MHCII in macrophages and DCs $(38,165,166)$. The question thus arises as to the nature of the antigens. Estrogen deficiency is likely to increase $\mathrm{T}$ cell reactivity to a pool of self and foreign antigens physiologically present in healthy animals and humans. As these antigens come into contact with immune cells locally and systemically, they induce a low grade T cell activation (167). Thus, a moderate immune response is constantly in place in healthy humans and rodents due to presentation by MHCII and MHCI molecules of both self and foreign peptides to $\mathrm{CD} 4^{+}$and $\mathrm{CD} 8^{+} \mathrm{T}$ cells (168). This response is thought to be essential for immune cell survival and renewal (169).

The effects of ovx on antigen presentation and the resulting changes in T cell activation, proliferation and lifespan are explained by a stimulatory effect of ovx on the expression of the gene encoding Class II Transactivator (CIITA). The product of CIITA is a non-DNA binding factor induced by IFN $\gamma$ that functions as a transcriptional coactivator at the MHC II promoter (170). Increased CIITA expression in macrophages derived from ovariectomized mice results from ovx-mediated increases in both $\mathrm{T}$ cell IFN $\gamma$ production and the responsiveness of CIITA to IFN $\gamma$ (38). The relevance of IFN $\gamma$ to ovx-induced bone loss is established by the failure of IFN $\gamma$ and IFN $\gamma$ receptor null mice to undergo T cell activation and to sustain bone loss in response to ovx $(37,38)$. 
One mechanism by which estrogen deficiency upregulates the production of IFN $\gamma$ is through TGF $\beta$. Estrogen has a direct stimulatory effect on the production of this factor which is mediated through direct binding of estrogen/ER complex to an ERE region in the TGF $\beta$ promoter (171). TGF $\beta$ is recognized a powerful repressor of T cell activation. Indeed, TGF $\beta$ exerts strong immunosuppressive effects by inhibiting the activation and the proliferation of $\mathrm{T}$ cells and their production of proinflammatory cytokines, including IFN $\gamma$. Studies in a transgenic mouse which expresses a dominant negative form of the TGF $\beta$ receptor exclusively in $\mathrm{T}$ cells have allowed the significance of the repressive effects of this cytokine on $\mathrm{T}$ cell function in the bone loss associated with estrogen deficiency to be established (158). This strain, known as CD4dnTGF $\beta$ RII, is severely osteopenic due to increased bone resorption. More importantly, mice with T cell-specific blockade of TGF $\beta$ signaling are completely resistant to the bone sparing effects of estrogen (158). This phenotype results from a failure of estrogen to repress IFN $\gamma$ production which, in turn, leads to increased $\mathrm{T}$ cell activation and $\mathrm{T}$ cell TNF production. Gain of function experiments confirmed that elevation of the systemic levels of TGF $\beta$ prevents ovx-induced bone loss and bone turnover (158).

Another mechanism by which estrogen regulates IFN $\gamma$ and TNF production is by repressing the production of IL-7. Importantly levels of IL-7 are significantly elevated following ovx $(32,172,173)$ and in vivo IL-7 blockade, using neutralizing antibodies, is effective in preventing ovx induced bone destruction (32) by suppressing T cell expansion and TNF and IFN $\gamma$ production (172). Furthermore, a recent study shows that liver-derived IGF-I is permissive for ovx-induced trabecular bone loss by modulation of the number of T-cells and the expression of IL-7 (173). The relevance of IL-7 in the mechanism of ovx induced bone loss has been confirmed, in part, by another recent investigation showing that ovx does not induce cortical bone loss in IL-7 KO mice (174). Indeed, the elevated BM levels of IL-7 contribute to the expansion of the T cell population in peripheral lymphoid organs through several mechanisms. Firstly, IL-7 directly stimulates T cell proliferation by lowering tolerance to weak self antigens. Secondly, IL-7 increases antigen presentation by upregulating the production of IFN $\gamma$. Thirdly, IL-7 and TGF $\beta$ inversely regulate each other's production $(175,176)$. The reduction in TGF $\beta$ signaling, characteristic of estrogen deficiency may serve to further stimulate IL-7 production, thus driving the cycle of osteoclastogenic cytokine production and bone wasting.

In estrogen deficiency IL-7 compounds bone loss by suppressing bone formation thus uncoupling bone formation from resorption.

\section{3. $T$ cell thymic output and bone loss}

The thymus undergoes progressive structural and functional declines with age, coinciding with increased circulating sex-steroid levels at puberty (177). By middle age most parenchymal tissue is replaced by fat, and in both mice and humans fewer $T$ cells are produced and exported to secondary lymphoid organs. However, the thymus continues to generate new $\mathrm{T}$ cells even into old age $(178,179)$. In fact, active lymphocytic thymic tissue has been documented in adults up to 107 years of age (180). Under severe T cell depletion secondary to HIV infection, chemotherapy or bone marrow transplant, an increase in thymic output (known as thymic rebound) becomes critical for long-term restoration of $\mathrm{T}$ cell homeostasis. For example, middle aged women treated with autologous bone marrow transplants develop thymic hypertrophy and a resurgence of thymic $\mathrm{T}$ cell output which contributes to the restoration of a wide $\mathrm{T}$ cell repertoire (181), although the intensity of thymic rebound declines with age.

The mechanism driving thymic rebound is not completely understood, but one factor involved is IL-7 (182). Importantly, IL-7 alone is not sufficient to enhance thymopoiesis in young mice (183), but plays a more relevant role in aged mice (184). 
Both androgens and estrogen have a profound suppressive effect on thymic function. Accordingly, castration reverses thymic atrophy and increases export of recent thymic emigrants to the periphery, $(185,186)$, while sex steroid inhibits thymus regeneration by promoting thymocyte apoptosis and an arrest of differentiation (187). Restoration of thymic function after castration occurs in young (188) as well as in very old rodents (189).

In accordance with the notion that estrogen deficiency induces a rebound in thymic function, ovx expands thymic T cells and leads to the thymic export of naïve T cells (172). Indeed, stimulated thymic T cell output accounts for $\sim 50 \%$ of the increase in the number of T cells in the periphery, while the remaining $50 \%$ is due to enhanced peripheral expansion. Confirming the functional link between $\mathrm{T}$ cell pool expansion and bone loss, thymectomy decreases by $50 \%$ the bone loss induced by ovx (172), thus demonstrating that the thymus plays a previously unrecognized causal effect in ovx induced bone loss in mice. The remaining bone loss is a consequence of the peripheral expansion of naïve and memory T cells (172). This finding, which awaits confirmation in humans, suggests that estrogen deficiency-induced thymic rebound may be responsible for the exaggerated bone loss in young women undergoing surgical menopause (190) or for the rapid bone loss characteristic of women in their first 5-7 years after natural menopause (128). Indeed, an age-related decrease in estrogen deficiency induced thymic rebound could mitigate the stimulatory effects of sex steroid deprivation and explain why the rate of bone loss in postmenopausal women diminishes as aging progresses (128).

\section{Estrogen, oxidative stress and $T$ cell dependent bone loss}

Recently, it has been suggested that reactive oxygen species (ROS) may play a role in postmenopausal bone loss by generating a more oxidized bone microenvironment $(191,192)$. In vivo support of this hypothesis is found from experiments in which ovx induces oxidative stress and impairs the expression of antioxidants in adult rats (193). Furthermore, administration of agents that increase the intracellular concentration of the antioxidant glutathione in bone prevent bone loss during estrogen deficiency in mice, while depletion of glutathione by buthionine sulfoximine (BSO), which inhibits glutathione synthesis, enhances bone loss (194). The nitric oxide (NO) donor nitroglycerin is also reported to prevent bone loss in ovariectomized rats $(195,196)$ while in the presence of N-nitro-l-arginine methyl ester (LNAME), an NO synthase inhibitor, estrogen was ineffective in reversing bone loss. This suggests that the protective effect of estrogen may be mediated in part through NO (195). In human studies nitroglycerin significantly prevented osteoporotic fractures in postmenopausal women (197).

OCs have been shown to both generate and be activated by ROS $(198,199)$. Glutathione peroxidase, responsible for intracellular degradation of hydrogen peroxide, is the predominant antioxidant enzyme expressed by OCs (200) and is upregulated by estrogen. Overexpression of glutathione peroxidase in the preosteoclastic cell line RAW 264.7 abolishes OC formation (200). This suppression of osteoclastic differentiation by antioxidants is likely to occur through protection of phosphatases from reversible inhibition by the ROS hydrogen peroxide (201), and by suppression of thioredoxin expression. Thioredoxin is induced by oxidative stress, and enhances OC formation (202). Consistent with a role for hydrogen peroxide in this pathway, catalase was found to prevent ovx induced bone loss in mice (200).

Estrogen enhances the levels of antioxidants in many cell lineages including the OC (194, 203). The expression of OC TNF is augmented by ROS. Bone loss caused by BSO has significant similarities to bone loss induced by estrogen deficiency, as both processes are TNFdependent (204). Moreover, soluble TNF receptors prevent both bone loss and the rise in thiolbased antioxidants characteristic of estrogen deficiency (204). 
Although the mechanisms of ROS action on bone during estrogen deficiency are poorly understood, among the biological targets of ROS are immune cells. ROS are important stimulators of antigen presentation by DCs, and DC induced T cell activation. Anti-oxidants potently inhibit DC differentiation and ability to activate T cells $(205,206)$ in part by suppressing expression of MHC class II and costimulatory molecules in response to antigen (207). N-Acetyl- Cystein (NAC), which acts as an intracellular scavenger by restoring intracellular concentration of glutathione, can block DC maturation (208) and DC-mediated T cell activation (209). ROS are also generated upon DC interaction with T cells (210) and can reduce $\mathrm{T}$ cell lifespan by stimulating T cell apoptosis (211). Interestingly, NAC treatment has been shown to protect against ovx-induced bone loss (194). These data are consistent with studies demonstrating that NAC treatment blunts ovx-induced DC activation in the BM, decreases antigen presentation and expression of costimulatory molecules, and prevents $\mathrm{T}$ cell activation and TNF production (77).

We have found that ovx increases the production of ROS in the BM, which lead to expansion of mature DCs which express the costimulatory molecule CD80, and increased DC mediated Ag presentation (77). This effect is tissue specific because ovx does not increase oxidative stress outside the BM. Attesting to the relevance of oxidative stress we have found that treatment with antioxidants blocks the stimulatory effects of ovx on DC and T cell activation and, and prevents ovx induced bone loss (77). Multiple enzymatic pathways regulate the intracellular redox state through modulation of ROS levels (212). Ovx blunts the BM levels of GSH, a critical ROS scavenger, and those of APE1/Ref-1 and Prx-1, proteins which contributes to limit the production of intracellular ROS (213). Like the activation of DCs, the effects of ovx on the redox state are spatially limited to the BM a phenomenon previously noted by Lean et al (194).

Taken together, these data suggest a model for ovx-induced bone loss in which estrogen deficiency lowers antioxidant levels, thereby increasing ROS, which in turn induces TNF expression by OCs directly, as well as by stimulating the APC-induced expansion of TNFproducing T cells central to bone destruction.

Other investigators have linked the bone wasting effects of ROS to its capacity to activate the transcription factor FoxO, a nuclear protein which mediates the capacity of estrogen to regulate OBs and OCs apoptosis and osteoblastogenesis $(145,148,214-216)$. This matter has been reviewed extensively elsewhere (145) and will not be discussed herein.

In summary, our data reveal that induction of oxidative stress is a localized upstream consequence of acute E deprivation, which leads to $\mathrm{Ag}$ dependent activation of T cells through upregulation of the costimulatory molecule CD80 on DCs. The downstream consequence of these events is increased T cell TNF production and bone loss. The capacity of CTLA4-Ig to prevent ovx induced bone loss confirms the role of activated $\mathrm{T}$ cells in the bone wasting effect of E deficiency and suggests that the CD80/28 pathway may represent a novel therapeutic target for postmenopausal bone loss.

\section{CONCLUSIONS}

Remarkable progress has been made in the last two decades in our understanding of the mechanisms of action of estrogen and PTH in bone. Most new data are derived from studies in mice and remain to be validated in humans, which will be essential for defining the role of the immune system in hyperparathyroidism and postmenopausal bone loss.

Since critical effects of estrogen and PTH on bone involve regulation of precursor cell differentiation and signaling pathways which are few and short-lived, many pivotal effects of estrogen and PTH in vivo are difficult to reproduce in vitro. Similarly, regulatory events 
observed in vitro are often not relevant in vivo. It is therefore essential for in vitro studies to be validated in vivo. For example, while estrogen stimulates IFN $\gamma$ production in cells in cultures (217), estrogen represses it in vivo (38). Similarly, while IFN $\gamma$ blocks OC formation through direct targeting of maturing OCs, IFN $\gamma$ stimulates osteoclastogenesis and bone resorption in estrogen deficient mice.

In summary, the multifaceted activities of estrogen and PTH are fully reflected in bone. Of the many surprises encountered investigating estrogen and PTH action in bone, a stunning one is the relationship between estrogen, the immune system and the skeleton. Clearly, if this relationship is equally relevant in humans as it is in rodents, postmenopausal osteoporosis and hyperparathyroidism should be regarded as the product of an inflammatory disorder bearing many characteristic of an organ limited autoimmune disorder, triggered by estrogen deficiency and overproduction of PTH.

\section{References}

1. Teitelbaum SL. Bone resorption by osteoclasts. Science 2000;289(5484):1504-8. [PubMed: 10968780]

2. Khosla S. Minireview: the OPG/RANKL/RANK system. Endocrinology 2001;142(12):5050-5. [PubMed: 11713196]

3. Weitzmann MN, Cenci S, Rifas L, Haug J, Dipersio J, Pacifici R. T cell activation induces human OC formation via receptor activator of nuclear factor kappaB ligand-dependent and -independent mechanisms. J Bone Miner Res 2001;16(2):328-37. [PubMed: 11204433]

4. Rifas L, Weitzmann MN. A novel T cell cytokine, secreted osteoclastogenic factor of activated T cells, induces OC formation in a RANKL-independent manner. Arthritis Rheum 2009;60(11):3324-35. [PubMed: 19877052]

5. Grey A, Mitnick MA, Masiukiewicz U, Sun BH, Rudikoff S, Jilka RL, Manolagas SC, Insogna K. A role for interleukin-6 in parathyroid hormone-induced bone resorption in vivo. Endocrinology 1999;140(10):4683-90. [PubMed: 10499526]

6. Pacifici R. Cytokines, estrogen and postmenopausal osteoporosis The second decade. Endocrinology 1998;139:2659-2661. [PubMed: 9607769]

7. Hofbauer LC, Lacey DL, Dunstan CR, Spelsberg TC, Riggs BL, Khosla S. Interleukin-1beta and tumor necrosis factor-alpha, but not interleukin- 6 , stimulate osteoprotegerin ligand gene expression in human osteoblastic cells. Bone 1999;25(3):255-9. [PubMed: 10495128]

8. Sherman ML, Weber BL, Datta R, Kufe DW. Transcriptional and posttranscriptional regulation of macrophage-specific colony stimulating factor gene expression by tumor necrosis factor. J Clin Invest 1990;85:442-447. [PubMed: 2105339]

9. Cenci S, Weitzmann MN, Roggia C, Namba N, Novack D, Woodring J, Pacifici R. Estrogen deficiency induces bone loss by enhancing T-cell production of TNF-alpha. J Clin Invest 2000;106(10):1229_ 1237. [PubMed: 11086024]

10. Lam J, Takeshita S, Barker JE, Kanagawa O, Ross FP, Teitelbaum SL. TNF-alpha induces osteoclastogenesis by direct stimulation of macrophages exposed to permissive levels of RANK ligand. J Clin Invest 2000;106(12):1481-1488. [PubMed: 11120755]

11. Zhang YH, Heulsmann A, Tondravi MM, Mukherjee A, Abu-Amer Y. Tumor necrosis factor-alpha (TNF) stimulates RANKL-induced osteoclastogenesis via coupling of TNF type 1 receptor and RANK signaling pathways. J Biol Chem 2001;276(1):563-8. [PubMed: 11032840]

12. Fuller K, Murphy C, Kirstein B, Fox SW, Chambers TJ. TNFalpha potently activates osteoclasts, through a direct action independent of and strongly synergistic with RANKL. Endocrinology 2002;143(3):1108-18. [PubMed: 11861538]

13. Kobayashi K, Takahashi N, Jimi E, Udagawa N, Takami M, Kotake S, Nakagawa N, Kinosaki M, Yamaguchi K, Shima N, Yasuda H, Morinaga T, Higashio K, Martin TJ, Suda T. Tumor Necrosis Factor alpha Stimulates OC Differentiation by a Mechanism Independent of the ODF/RANKLRANK Interaction. J Exp Med 2000;191(2):275-286. [PubMed: 10637272] 
14. Kim N, Kadono Y, Takami M, Lee J, Lee SH, Okada F, Kim JH, Kobayashi T, Odgren PR, Nakano H, Yeh WC, Lee SK, Lorenzo JA, Choi Y. OC differentiation independent of the TRANCE-RANKTRAF6 axis. J Exp Med 2005;202(5):589-95. [PubMed: 16147974]

15. Nanes MS. Tumor necrosis factor-alpha: molecular and cellular mechanisms in skeletal pathology. Gene 2003;321:1-15. [PubMed: 14636987]

16. Roggia C, Gao Y, Cenci S, Weitzmann MN, Toraldo G, Isaia G, Pacifici R. Upregulation of TNFproducing T cells in the bone marrow: A key mechanism by which estrogen deficiency induces bone loss in vivo. Proc Natl Acad Sci U S A 2001;98(24):13960-5. [PubMed: 11717453]

17. Ammann P, Rizzoli R, Bonjour JP, Bourrin S, Meyer JM, Vassalli P, Garcia I. Transgenic mice expressing soluble tumor necrosis factor-receptor are protected against bone loss caused by estrogen deficiency. J Clin Invest 1997;99:1699-1703. [PubMed: 9120014]

18. Kimble R, Bain S, Pacifici R. The functional block of TNF but not of IL-6 prevents bone loss in ovariectomized mice. J Bone Min Res 1997;12:935-941.

19. Wei S, Kitaura H, Zhou P, Ross FP, Teitelbaum SL. IL-1 mediates TNF-induced osteoclastogenesis. J Clin Invest 2005;115(2):282-90. [PubMed: 15668736]

20. Kwan Tat S, Padrines M, Theoleyre S, Heymann D, Fortun Y. IL-6, RANKL, TNFalpha/IL-1: interrelations in bone resorption pathophysiology. Cytokine Growth Factor Rev 2004;15(1):49-60. [PubMed: 14746813]

21. Ross FP. Interleukin 7 and estrogen-induced bone loss. Trends Endocrinol Metab 2003;14(4):1479. [PubMed: 12714270]

22. Miyaura C, Onoe Y, Inada M, Maki K, Ikuta K, Ito M, Suda T. Increased Blymphopoiesis by interleukin 7 induces bone loss in mice with intact ovarian function: similarity to estrogen deficiency. Proc Natl Acad Sci USA 1997;19:9360-9365. [PubMed: 9256487]

23. Sato T, Shibata T, Ikeda K, Watanabe K. Generation of bone-resorbing osteoclasts from B220+ cells: its role in accelerated osteoclastogenesis due to estrogen deficiency. J Bone Miner Res 2001;16(12): 2215-21. [PubMed: 11760834]

24. Onoe Y, Miyaura C, Ito M, Ohta H, Nozawa S, Suda T. Comparative effects of estrogen and raloxifene on B lymphopoiesis and bone loss induced by sex steroid deficiency in mice. J Bone Miner Res 2000;15(3):541-9. [PubMed: 10750569]

25. Masuzawa T, Miyaura C, Onoe Y, Kusano K, Ohta H, Nozawa S, Suda T. Estrogen deficiency stimulates B lymphopoiesis in mouse bone marrow. J Clin Invest 1994;94:1090-1097. [PubMed: 8083350]

26. Manabe N, Kawaguchi H, Chikuda H, Miyaura C, Inada M, Nagai R, Nabeshima Y, Nakamura K, Sinclair AM, Scheuermann RH, Kuro-o M. Connection between B lymphocyte and OC differentiation pathways. J Immunol 2001;167(5):2625-31. [PubMed: 11509604]

27. Fry TJ, Mackall CL. Interleukin-7: master regulator of peripheral T-cell homeostasis? Trends Immunol 2001;22(10):564-71. [PubMed: 11574281]

28. von Freeden-Jeffry U, Vieira P, Lucian LA, McNeil T, Burdach SE, Murray R. Lymphopenia in interleukin (IL)-7 gene-deleted mice identifies IL-7 as a nonredundant cytokine. J Exp Med 1995;181 (4):1519-26. [PubMed: 7699333]

29. Valenzona HO, Pointer R, Ceredig R, Osmond DG. Prelymphomatous B cell hyperplasia in the bone marrow of interleukin-7 transgenic mice: precursor $\mathrm{B}$ cell dynamics, microenvironmental organization and osteolysis. Exp Hematol 1996;24(13):1521-9. [PubMed: 8950236]

30. Weitzmann MN, Cenci S, Rifas L, Brown C, Pacifici R. Interleukin-7 stimulates OC formation by up-regulating the T- cell production of soluble osteoclastogenic cytokines. Blood 2000;96(5):18738. [PubMed: 10961889]

31. Toraldo G, Roggia C, Qian W-P, Pacifici R, Weitzmann MN. IL-7 induces bone loss in vivo by induction of receptor activator of nuclear factor kappa B ligand and tumor necrosis factor alpha from T cells. 2003;100:125-130.

32. Weitzmann MN, Roggia C, Toraldo G, Weitzmann L, Pacifici R. Increased production of IL-7 uncouples bone formation from bone resorption during estrogen deficiency. J Clin Invest 2002;110 (11):1643-50. [PubMed: 12464669] 
33. Takayanagi H, Ogasawara K, Hida S, Chiba T, Murata S, Sato K, Takaoka A, Yokochi T, Oda H, Tanaka K, Nakamura K, Taniguchi T. T-cell-mediated regulation of osteoclastogenesis by signalling cross- talk between RANKL and IFN-gamma. Nature 2000;408(6812):600-5. [PubMed: 11117749]

34. Vermeire K, Heremans H, Vandeputte M, Huang S, Billiau A, Matthys P. Accelerated collageninduced arthritis in IFN-gamma receptor-deficient mice. J Immunol 1997;158(11):5507-13. [PubMed: 9164974]

35. Sato K, Satoh T, Shizume K, Yamakawa Y, Ono Y, Demura H, Akatsu T, Takahashi N, Suda T. Prolonged decrease of serum calcium concentration by murine gamma-interferon in hypercalcemic, human tumor (EC-GI)-bearing nude mice. Cancer Res 1992;52(2):444-9. [PubMed: 1728416]

36. Tohkin M, Kakudo S, Kasai H, Arita H. Comparative study of inhibitory effects by murine interferon gamma and a new bisphosphonate (alendronate) in hypercalcemic, nude mice bearing human tumor (LJC-1-JCK). Cancer Immunol Immunother 1994;39(3):155-60. [PubMed: 7522963]

37. Gao Y, Grassi F, Ryan MR, Terauchi M, Page K, Yang X, Weitzmann MN, Pacifici R. IFN-gamma stimulates OC formation and bone loss in vivo via antigen-driven T cell activation. J Clin Invest 2007;117(1):122-32. [PubMed: 17173138]

38. Cenci S, Toraldo G, Weitzmann MN, Roggia C, Gao Y, Qian WP, Sierra O, Pacifici R. Estrogen deficiency induces bone loss by increasing T cell proliferation and lifespan through IFN-gammainduced class II transactivator. Proc Natl Acad Sci U S A 2003;100(18):10405-10. [PubMed: 12923292]

39. Baker PJ, Dixon M, Evans RT, Dufour L, Johnson E, Roopenian DC. CD4(+) T cells and the proinflammatory cytokines gamma interferon and interleukin- 6 contribute to alveolar bone loss in mice. Infect Immun 1999;67(6):2804-9. [PubMed: 10338484]

40. Arnoldi J, Gerdes J, Flad HD. Immunohistologic assessment of cytokine production of infiltrating cells in various forms of leprosy. Am J Pathol 1990;137(4):749-53. [PubMed: 2121040]

41. Firestein GS, Alvaro-Gracia JM, Maki R, Alvaro-Garcia JM. Quantitative analysis of cytokine gene expression in rheumatoid arthritis. J Immunol 1990;144(9):3347-53. [PubMed: 2109776]

42. Cannon GW, Pincus SH, Emkey RD, Denes A, Cohen SA, Wolfe F, Saway PA, Jaffer AM, Weaver $\mathrm{AL}, \mathrm{Cogen} \mathrm{L}$, et al. Double-blind trial of recombinant gamma-interferon versus placebo in the treatment of rheumatoid arthritis. Arthritis Rheum 1989;32(8):964-73. [PubMed: 2504171]

43. Veys EM, Menkes CJ, Emery P. A randomized, double-blind study comparing twenty-four-week treatment with recombinant interferon-gamma versus placebo in the treatment of rheumatoid arthritis. Arthritis Rheum 1997;40(1):62-8. [PubMed: 9008601]

44. Mann GN, Jacobs TW, Buchinsky FJ, Armstrong EC, Li M, Ke HZ, Ma YF, Jee WS, Epstein S. Interferon-gamma causes loss of bone volume in vivo and fails to ameliorate cyclosporin A-induced osteopenia. Endocrinology 1994;135:1077-1083. [PubMed: 8070349]

45. Key LL Jr, Rodriguiz RM, Willi SM, Wright NM, Hatcher HC, Eyre DR, Cure JK, Griffin PP, Ries WL. Long-term treatment of osteopetrosis with recombinant human interferon gamma. N Engl J Med 1995;332(24):1594-9. [PubMed: 7753137]

46. Rodriguiz RM, Key LL Jr, Ries WL. Combination macrophage-colony stimulating factor and interferon-gamma administration ameliorates the osteopetrotic condition in microphthalmic (mi/mi) mice. Pediatr Res 1993;33(4 Pt 1):384-9. [PubMed: 8479820]

47. Fox SW, Chambers TJ. Interferon-gamma directly inhibits TRANCE-induced osteoclastogenesis. Biochem Biophys Res Commun 2000;276(3):868-72. [PubMed: 11027561]

48. Quinn JM, Sims NA, Saleh H, Mirosa D, Thompson K, Bouralexis S, Walker EC, Martin TJ, Gillespie MT. IL-23 inhibits osteoclastogenesis indirectly through lymphocytes and is required for the maintenance of bone mass in mice. J Immunol 2008;181(8):5720-9. [PubMed: 18832731]

49. Abbas, AK.; Lichtman, AH.; Pober, JS. Cellular and Molecular Immunology. Fourth. W.B Saunders Company; St Louis: 2000.

50. Godfrey DI, MacDonald HR, Kronenberg M, Smyth MJ, Van Kaer L. NKT cells: what's in a name? Nat Rev Immunol 2004;4(3):231-7. [PubMed: 15039760]

51. Sato K, Suematsu A, Okamoto K, Yamaguchi A, Morishita Y, Kadono Y, Tanaka S, Kodama T, Akira S, Iwakura Y, Cua DJ, Takayanagi H. Th17 functions as an osteoclastogenic helper T cell subset that links T cell activation and bone destruction. J Exp Med 2006;203(12):2673-82. [PubMed: 17088434] 
52. Kotake S, Udagawa N, Takahashi N, Matsuzaki K, Itoh K, Ishiyama S, Saito S, Inoue K, Kamatani N, Gillespie MT, Martin TJ, Suda T. IL-17 in synovial fluids from patients with rheumatoid arthritis is a potent stimulator of osteoclastogenesis. J Clin Invest 1999;103(9):1345-52. [PubMed: 10225978]

53. Polanczyk MJ, Carson BD, Subramanian S, Afentoulis M, Vandenbark AA, Ziegler SF, Offner H. Cutting edge: estrogen drives expansion of the CD4+CD25+ regulatory T cell compartment. J Immunol 2004;173(4):2227-30. [PubMed: 15294932]

54. Di Rosa F, Pabst R. The bone marrow: a nest for migratory memory T cells. Trends Immunol 2005;26 (7):360-366. [PubMed: 15978522]

55. Feuerer M, Beckhove P, Garbi N, Mahnke Y, Limmer A, Hommel M, Hammerling GJ, Kyewski B, Hamann A, Umansky V, Schirrmacher V. Bone marrow as a priming site for Tcell responses to bloodborne antigen. Nat Med 2003;9(9):1151-7. [PubMed: 12910264]

56. Tripp RA, Topham DJ, Watson SR, Doherty PC. Bone marrow can function as a lymphoid organ during a primary immune response under conditions of disrupted lymphocyte trafficking. J Immunol 1997;158(8):3716-20. [PubMed: 9103435]

57. Kong YY, Feige U, Sarosi I, Bolon B, Tafuri A, Morony S, Capparelli C, Li J, Elliott R, McCabe S, Wong T, Campagnuolo G, Moran E, Bogoch ER, Van G, Nguyen LT, Ohashi PS, Lacey DL, Fish E, Boyle WJ, Penninger JM. Activated T cells regulate bone loss and joint destruction in adjuvant arthritis through osteoprotegerin ligand. Nature 1999;402(6759):304-9. [PubMed: 10580503]

58. Teng YT, Nguyen H, Gao X, Kong YY, Gorczynski RM, Singh B, Ellen RP, Penninger JM. Functional human T-cell immunity and osteoprotegerin ligand control alveolar bone destruction in periodontal infection. J Clin Invest 2000;106(6):59-67.

59. Weitzmann MN, Pacifici R. Estrogen deficiency and bone loss: an inflammatory tale. J Clin Invest 2006;116(5):1186-94. [PubMed: 16670759]

60. Pacifici R. Estrogen deficiency, T cells and bone loss. Cell Immunol 2008;252(1-2):68-80. [PubMed: 17888417]

61. Yamaza T, Miura Y, Bi Y, Liu Y, Akiyama K, Sonoyama W, Patel V, Gutkind S, Young M, Gronthos S, Le A, Wang CY, Chen W, Shi S. Pharmacologic stem cell based intervention as a new approach to osteoporosis treatment in rodents. PLoS ONE 2008;3(7):e2615. [PubMed: 18612428]

62. John V, Hock JM, Short LL, Glasebrook AL, Galvin RJ. A role for CD8+ T lymphocytes in OC differentiation in vitro. Endocrinology 1996;137(6):2457-63. [PubMed: 8641199]

63. Kim YG, Lee CK, Nah SS, Mun SH, Yoo B, Moon HB. Human CD4+CD25+ regulatory T cells inhibit the differentiation of osteoclasts from peripheral blood mononuclear cells. Biochem Biophys Res Commun 2007;357(4):1046-52. [PubMed: 17462597]

64. Ernst CW, Lee JE, Nakanishi T, Karimbux NY, Rezende TM, Stashenko P, Seki M, Taubman MA, Kawai T. Diminished forkhead box P3/CD25 double-positive T regulatory cells are associated with the increased nuclear factor-kappaB ligand (RANKL+) T cells in bone resorption lesion of periodontal disease. Clin Exp Immunol 2007;148(2):271-80. [PubMed: 17355249]

65. Grcevic D, Lee SK, Marusic A, Lorenzo JA. Depletion of CD4 and CD8 T lymphocytes in mice In vivo enhances 1,25 - dihydroxyvitamin $\mathrm{D}$ (3)-stimulated OC-like cell formation In vitro by a mechanism that is dependent on prostaglandin synthesis. J Immunol 2000;165(8):4231-8. [PubMed: 11035056]

66. Grcevic D, Lukic IK, Kovacic N, Ivcevic S, Katavic V, Marusic A. Activated T lymphocytes suppress osteoclastogenesis by diverting early monocyte/macrophage progenitor lineage commitment towards dendritic cell differentiation through down-regulation of receptor activator of nuclear factor-kappaB and c-Fos. Clin Exp Immunol 2006;146(1):146-58. [PubMed: 16968409]

67. Horwood NJ, Kartsogiannis V, Quinn JM, Romas E, Martin TJ, Gillespie MT. Activated T lymphocytes support OC formation in vitro. Biochem Biophys Res Commun 1999;265(1):144-50. [PubMed: 10548505]

68. Wyzga N, Varghese S, Wikel S, Canalis E, Sylvester FA. Effects of activated T cells on osteoclastogenesis depend on how they are activated. Bone 2004;35(3):614-20. [PubMed: 15336596]

69. Li Y, Toraldo G, Li A, Yang X, Zhang H, Qian WP, Weitzmann MN. B cells and T cells are critical for the preservation of bone homeostasis and attainment of peak bone mass in vivo. Blood 2007;109 (9):3839-48. [PubMed: 17202317] 
70. Yasuda H, Shima N, Nakagawa N, Yamaguchi K, Kinosaki M, Mochizuki S, Tomoyasu A, Yano K, Goto M, Murakami A, Tsuda E, Morinaga T, Higashio K, Udagawa N, Takahashi N, Suda T. OC differentiation factor is a ligand for osteoprotegerin/osteoclastogenesisinhibitory factor and is identical to TRANCE/RANKL. Proc Natl Acad Sci U S A 1998;95(7):3597-602. [PubMed: 9520411]

71. Udagawa N, Takahashi N, Yasuda H, Mizuno A, Itoh K, Ueno Y, Shinki T, Gillespie MT, Martin TJ, Higashio K, Suda T. Osteoprotegerin produced by osteoblasts is an important regulator in OC development and function. Endocrinology 2000;141(9):3478-84. [PubMed: 10965921]

72. Li Y, Li A, Yang X, Weitzmann MN. Ovariectomy-induced bone loss occurs independently of B cells. J Cell Biochem 2007;100(6):1370-5. [PubMed: 17131364]

73. Yun TJ, Chaudhary PM, Shu GL, Frazer JK, Ewings MK, Schwartz SM, Pascual V, Hood LE, Clark EA. OPG/FDCR-1, a TNF receptor family member, is expressed in lymphoid cells and is up-regulated by ligating CD40. J Immunol 1998;161(11):6113-21. [PubMed: 9834095]

74. O’Brien C, Fu Q, Mommsen L, Dusevich V, Bonewald L, Manolagas SC, Jilka RL. Osteoblasts are not the source of RANKL and OPG in bone but are required for maintenance of OC function. Journal Bone Mineral Research 2006;22(Supplement 1) abstract.

75. Polanczyk MJ, Hopke C, Huan J, Vandenbark AA, Offner H. Enhanced FoxP3 expression and Treg cell function in pregnant and estrogen-treated mice. J Neuroimmunol 2005;170(1-2):85-92. [PubMed: 16253347]

76. Polanczyk MJ, Hopke C, Vandenbark AA, Offner H. Estrogen-mediated immunomodulation involves reduced activation of effector T cells, potentiation of Treg cells, and enhanced expression of the PD-1 costimulatory pathway. J Neurosci Res 2006;84(2):370-8. [PubMed: 16676326]

77. Grassi F, Tell G, Robbie-Ryan M, Gao Y, Terauchi M, Yang X, Romanello M, Jones DP, Weitzmann MN, Pacifici R. Oxidative stress causes bone loss in estrogen-deficient mice through enhanced bone marrow dendritic cell activation. Proc Natl Acad Sci U S A 2007;104(38):15087-92. [PubMed: 17848519]

78. Riggs BL, Melton LJ. Medical progress: involutional osteoporosis. N Eng J Med 1986;314:16761684.

79. Grey AB, Stapleton JP, Evans MC, Reid IR. Accelerated bone loss in postmenopausal women with mild primary hyperparathyroidism. Clin Endocrinol (Oxf) 1996;44(6):697-702. [PubMed: 8759182]

80. Potts, J. Primary hyperparathyroidism. In: Avioli, LV.; Krane, S., editors. Metabolic Bone Diseases. \#. Vol. 1. Academic Press; San Diego: 1998. p. 411-442.

81. Neer RM, Arnaud CD, Zanchetta JR, Prince R, Gaich GA, Reginster JY, Hodsman AB, Eriksen EF, Ish-Shalom S, Genant HK, Wang O, Mitlak BH. Effect of parathyroid hormone (1-34) on fractures and bone mineral density in postmenopausal women with osteoporosis. N Engl J Med 2001;344(19): 1434-41. [PubMed: 11346808]

82. Canalis E, Giustina A, Bilezikian JP. Mechanisms of anabolic therapies for osteoporosis. N Engl J Med 2007;357(9):905-16. [PubMed: 17761594]

83. Calvi LM, Sims NA, Hunzelman JL, Knight MC, Giovannetti A, Saxton JM, Kronenberg HM, Baron R, Schipani E. Activated parathyroid hormone/parathyroid hormone-related protein receptor in osteoblastic cells differentially affects cortical and trabecular bone. J Clin Invest 2001;107(3):27786. [PubMed: 11160151]

84. Qin L, Raggatt LJ, Partridge NC. Parathyroid hormone: a double-edged sword for bone metabolism. Trends Endocrinol Metab 2004;15(2):60-5. [PubMed: 15036251]

85. Lanske B, Amling M, Neff L, Guiducci J, Baron R, Kronenberg HM. Ablation of the PTHrP gene or the PTH/PTHrP receptor gene leads to distinct abnormalities in bone development. J Clin Invest 1999;104(4):399-407. [PubMed: 10449432]

86. O’Brien CA, Plotkin LI, Galli C, Goellner JJ, Gortazar AR, Allen MR, Robling AG, Bouxsein M, Schipani E, Turner CH, Jilka RL, Weinstein RS, Manolagas SC, Bellido T. Control of bone mass and remodeling by PTH receptor signaling in osteocytes. PLoS ONE 2008;3(8):e2942. [PubMed: 18698360]

87. Lindsay R, Cosman F, Zhou H, Bostrom MP, Shen VW, Cruz JD, Nieves JW, Dempster DW. A novel tetracycline labeling schedule for longitudinal evaluation of the short-term effects of anabolic therapy 
with a single iliac crest bone biopsy: early actions of teriparatide. J Bone Miner Res 2006;21(3):36673. [PubMed: 16491283]

88. Ma YL, Zeng Q, Donley DW, Ste-Marie LG, Gallagher JC, Dalsky GP, Marcus R, Eriksen EF. Teriparatide increases bone formation in modeling and remodeling osteons and enhances IGF-II immunoreactivity in postmenopausal women with osteoporosis. J Bone Miner Res 2006;21(6):85564. [PubMed: 16753016]

89. Dobnig H, Turner RT. The effects of programmed administration of human parathyroid hormone fragment (1-34) on bone histomorphometry and serum chemistry in rats. Endocrinology 1997;138 (11):4607-12. [PubMed: 9348185]

90. Dobnig H, Turner RT. Evidence that intermittent treatment with parathyroid hormone increases bone formation in adult rats by activation of bone lining cells. Endocrinology 1995;136(8):3632-8. [PubMed: 7628403]

91. Nishida S, Yamaguchi A, Tanizawa T, Endo N, Mashiba T, Uchiyama Y, Suda T, Yoshiki S, Takahashi HE. Increased bone formation by intermittent parathyroid hormone administration is due to the stimulation of proliferation and differentiation of osteoprogenitor cells in bone marrow. Bone 1994;15(6):717-23. [PubMed: 7873302]

92. Pettway GJ, Meganck JA, Koh AJ, Keller ET, Goldstein SA, McCauley LK. Parathyroid hormone mediates bone growth through the regulation of osteoblast proliferation and differentiation. Bone 2008;42(4):806-18. [PubMed: 18234576]

93. Schmidt IU, Dobnig H, Turner RT. Intermittent parathyroid hormone treatment increases osteoblast number, steady state messenger ribonucleic acid levels for osteocalcin, and bone formation in tibial metaphysis of hypophysectomized female rats. Endocrinology 1995;136(11):5127-34. [PubMed: 7588250]

94. Jilka RL, Weinstein RS, Bellido T, Roberson P, Parfitt AM, Manolagas SC. Increased bone formation by prevention of osteoblast apoptosis with parathyroid hormone. J Clin Invest 1999;104(4):439-46. [PubMed: 10449436]

95. Bellido T, Ali AA, Plotkin LI, Fu Q, Gubrij I, Roberson PK, Weinstein RS, O’Brien CA, Manolagas SC, Jilka RL. Proteasomal degradation of Runx2 shortens parathyroid hormone-induced antiapoptotic signaling in osteoblasts. A putative explanation for why intermittent administration is needed for bone anabolism. J Biol Chem 2003;278(50):50259-72. [PubMed: 14523023]

96. Almeida M, Han L, Bellido T, Manolagas SC, Kousteni S. Wnt proteins prevent apoptosis of both uncommitted osteoblast progenitors and differentiated osteoblasts by betacatenin- dependent and independent signaling cascades involving Src/ERK and phosphatidylinositol 3-kinase/AKT. J Biol Chem 2005;280(50):41342-51. [PubMed: 16251184]

97. Tobimatsu T, Kaji H, Sowa H, Naito J, Canaff L, Hendy GN, Sugimoto T, Chihara K. Parathyroid hormone increases beta-catenin levels through Smad3 in mouse osteoblastic cells. Endocrinology 2006;147(5):2583-90. [PubMed: 16484320]

98. Pfeilschifter J, Laukhuf F, Muller-Beckmann B, Blum WF, Pfister T, Ziegler R. Parathyroid hormone increases the concentration of insulin-like growth factor-I and transforming growth factor beta 1 in rat bone. J Clin Invest 1995;96(2):767-74. [PubMed: 7635970]

99. Hurley MM, Okada Y, Xiao L, Tanaka Y, Ito M, Okimoto N, Nakamura T, Rosen CJ, Doetschman T, Coffin JD. Impaired bone anabolic response to parathyroid hormone in Fgf2-/- and Fgf2+/- mice. Biochem Biophys Res Commun 2006;341(4):989-94. [PubMed: 16455048]

100. Jilka RL. Molecular and cellular mechanisms of the anabolic effect of intermittent PTH. Bone 2007;40(6):1434-46. [PubMed: 17517365]

101. Moon RT, Bowerman B, Boutros M, Perrimon N. The promise and perils of Wnt signaling through beta-catenin. Science 2002;296(5573):1644-6. [PubMed: 12040179]

102. Kato M, Patel MS, Levasseur R, Lobov I, Chang BH, Glass DA 2, Hartmann C, Li L, Hwang TH, Brayton CF, Lang RA, Karsenty G, Chan L. Cbfa1-independent decrease in osteoblast proliferation, osteopenia, and persistent embryonic eye vascularization in mice deficient in Lrp5, a Wnt coreceptor. J Cell Biol 2002;157(2):303-14. [PubMed: 11956231]

103. Bodine PV, Komm BS. Wnt signaling and osteoblastogenesis. Rev Endocr Metab Disord 2006;7 (1-2):33-9. [PubMed: 16960757] 
104. Bodine PV, Billiard J, Moran RA, Ponce-de-Leon H, McLarney S, Mangine A, Scrimo MJ, Bhat RA, Stauffer B, Green J, Stein GS, Lian JB, Komm BS. The Wnt antagonist secreted frizzled-related protein-1 controls osteoblast and osteocyte apoptosis. J Cell Biochem 2005;96(6):1212-30. [PubMed: 16149051]

105. Glass DA 2nd, Bialek P, Ahn JD, Starbuck M, Patel MS, Clevers H, Taketo MM, Long F, McMahon AP, Lang RA, Karsenty G. Canonical Wnt signaling in differentiated osteoblasts controls OC differentiation. Dev Cell 2005;8(5):751-64. [PubMed: 15866165]

106. Choi HY, Dieckmann M, Herz J, Niemeier A. Lrp4, a novel receptor for Dickkopf 1 and sclerostin, is expressed by osteoblasts and regulates bone growth and turnover in vivo. PLoS One 2009;4 (11):e7930. [PubMed: 19936252]

107. Behrens J, von Kries JP, Kuhl M, Bruhn L, Wedlich D, Grosschedl R, Birchmeier W. Functional interaction of beta-catenin with the transcription factor LEF-1. Nature 1996;382(6592):638-42. [PubMed: 8757136]

108. Kulkarni NH, Halladay DL, Miles RR, Gilbert LM, Frolik CA, Galvin RJ, Martin TJ, Gillespie MT, Onyia JE. Effects of parathyroid hormone on Wnt signaling pathway in bone. J Cell Biochem 2005;95(6):1178-90. [PubMed: 15962290]

109. Wan M, Yang C, Li J, Wu X, Yuan H, Ma H, He X, Nie S, Chang C, Cao X. Parathyroid hormone signaling through low-density lipoprotein-related protein 6. Genes Dev 2008;22(21):2968-79. [PubMed: 18981475]

110. Bellido T, Ali AA, Gubrij I, Plotkin LI, Fu Q, O’Brien CA, Manolagas SC, Jilka RL. Chronic elevation of parathyroid hormone in mice reduces expression of sclerostin by osteocytes: a novel mechanism for hormonal control of osteoblastogenesis. Endocrinology 2005;146(11):4577-83. [PubMed: 16081646]

111. Keller H, Kneissel M. SOST is a target gene for PTH in bone. Bone 2005;37(2):148-58. [PubMed: 15946907]

112. Qin L, Qiu P, Wang L, Li X, Swarthout JT, Soteropoulos P, Tolias P, Partridge NC. Gene expression profiles and transcription factors involved in parathyroid hormone signaling in osteoblasts revealed by microarray and bioinformatics. J Biol Chem 2003;278(22):19723-31. [PubMed: 12644456]

113. Kramer I, Loots GG, Studer A, Keller H, Kneissel M. Parathyroid Hormone (PTH) Induced Bone Gain is Blunted in SOST Overexpressing and Deficient Mice. J Bone Miner Res 2010;25:178-189. [PubMed: 19594304]

114. Sims NA. Building bone with a SOST-PTH partnership. J Bone Miner Res 2010;25(2):175-7. [PubMed: 20175218]

115. Qiu T, Wu T, Zhang F, Clemens TL, Wan M, Cao X. TGF-beta type II receptor phosphorylates PTH receptor to integrate bone remodelling signalling. Nat Cell Biol 2010;12(3):224-34. [PubMed: 20139972]

116. Stojceva-Taneva O, Fadda GZ, Smogorzewski M, Massry SG. Parathyroid hormone increases cytosolic calcium of thymocytes. Nephron 1993;64(4):592-9. [PubMed: 8396211]

117. Geffner ME, Bersch N, Cortez AB, Bailey RC, Golde DW. Growth-promoting actions of parathyroid hormone, adrenocorticotrophic hormone, and thyroid-stimulating hormone: in vitro studies in normal and pygmy T-lymphoblast cell lines. Pediatr Res 1995;37(4 Pt 1):507-11. [PubMed: 7596693]

118. Rifas L. T-cell cytokine induction of BMP-2 regulates human mesenchymal stromal cell differentiation and mineralization. J Cell Biochem 2006;98(4):706-14. [PubMed: 16619272]

119. Rifas L, Arackal S. T cells regulate the expression of matrix metalloproteinase in human osteoblasts via a dual mitogen-activated protein kinase mechanism. Arthritis Rheum 2003;48(4):993-1001. [PubMed: 12687541]

120. Rifas L, Arackal S, Weitzmann MN. Inflammatory T cells rapidly induce differentiation of human bone marrow stromal cells into mature osteoblasts. J Cell Biochem 2003;88(4):650-9. [PubMed: 12577299]

121. Guise TA, Chirgwin JM, Favarato G, Boyce BF, Mundy GR. Chinese hamster ovarian cells transfected with human parathyroid hormone-related protein cDNA cause hypercalcemia in nude mice. Lab Invest 1992;67(4):477-85. [PubMed: 1434529] 
122. Mehdizadeh S, Alaghband-Zadeh J, Gusterson B, Arlot M, Bradbeer JN, Loveridge N. Bone resorption and circulating PTH-like bioactivity in an animal model of hypercalcaemia of malignancy. Biochem Biophys Res Commun 1989;161(3):1166-71. [PubMed: 2742581]

123. Uy HL, Guise TA, De La Mata J, Taylor SD, Story BM, Dallas MR, Boyce BF, Mundy GR, Roodman GD. Effects of parathyroid hormone (PTH)-related protein and PTH on osteoclasts and OC precursors in vivo. Endocrinology 1995;136(8):3207-12. [PubMed: 7628353]

124. Hory BG, Roussanne MC, Rostand S, Bourdeau A, Drueke TB, Gogusev J. Absence of response to human parathyroid hormone in athymic mice grafted with human parathyroid adenoma, hyperplasia or parathyroid cells maintained in culture. J Endocrinol Invest 2000;23(5):273-9. [PubMed: 10882144]

125. Gao Y, Wu X, Terauchi M, Li JY, Grassi F, Galley S, Yang X, Weitzmann MN, Pacifici R. T cells potentiate PTH-induced cortical bone loss through CD40L signaling. Cell Metab 2008;8(2):13245. [PubMed: 18680714]

126. Tanaka Y, Maruo A, Fujii K, Nomi M, Nakamura T, Eto S, Minami Y. Intercellular adhesion molecule 1 discriminates functionally different populations of human osteoblasts: characteristic involvement of cell cycle regulators. J Bone Miner Res 2000;15(10):1912-23. [PubMed: 11028443]

127. Everts V, Delaisse JM, Korper W, Jansen DC, Tigchelaar-Gutter W, Saftig P, Beertsen W. The bone lining cell: its role in cleaning Howship's lacunae and initiating bone formation. J Bone Miner Res 2002;17(1):77-90. [PubMed: 11771672]

128. Riggs BL, Khosla S, Melton LJ 3. Sex steroids and the construction and conservation of the adult skeleton. Endocr Rev 2002;23(3):279-302. [PubMed: 12050121]

129. Cheng X, Li J, Lu Y, Keyak J, Lang T. Proximal femoral density and geometry measurements by quantitative computed tomography: association with hip fracture. Bone 2007;40(1):169-74. [PubMed: 16876496]

130. Parisien, M.; Dempster, DW.; Shane, E.; Bilezikian, JP. Basic and clinical concepts. Academic Press; San Diego: 2001. Histomorphometric analysis of bone in primary hyperparathyroidism The parathyroids; p. 423-436.

131. Di Rosa F, Santoni A. Memory T-cell competition for bone marrow seeding. Immunology 2003;108 (3):296-304. [PubMed: 12603595]

132. Moreland L, Bate G, Kirkpatrick P. Abatacept. Nat Rev Drug Discov 2006;5(3):185-6. [PubMed: 16557658]

133. Ruderman EM, Pope RM. The evolving clinical profile of abatacept (CTLA4-Ig): a novel costimulatory modulator for the treatment of rheumatoid arthritis. Arthritis Res Ther 2005;7(Suppl 2):S21-5. [PubMed: 15833145]

134. Pettway GJ, Schneider A, Koh AJ, Widjaja E, Morris MD, Meganck JA, Goldstein SA, McCauley LK. Anabolic actions of PTH (1-34): use of a novel tissue engineering model to investigate temporal effects on bone. Bone 2005;36(6):959-70. [PubMed: 15878317]

135. Terauchi M, Li JY, Bedi B, Baek KH, Tawfeek H, Galley S, Gilbert L, Nanes MS, Zayzafoon M, Guldberg R, Lamar DL, Singer MA, Lane TF, Kronenberg HM, Weitzmann MN, Pacifici R. T lymphocytes amplify the anabolic activity of parathyroid hormone through Wnt10b signaling. Cell Metab 2009;10(3):229-40. [PubMed: 19723499]

136. Di Rosa F. T-lymphocyte interaction with stromal, bone and hematopoietic cells in the bone marrow. Immunol Cell Biol 2008;87:20-29. [PubMed: 19030018]

137. Rawadi G, Vayssiere B, Dunn F, Baron R, Roman-Roman S. BMP-2 controls alkaline phosphatase expression and osteoblast mineralization by a Wnt autocrine loop. J Bone Miner Res 2003;18(10): 1842-53. [PubMed: 14584895]

138. Luo Q, Kang Q, Si W, Jiang W, Park JK, Peng Y, Li X, Luu HH, Luo J, Montag AG, Haydon RC, He TC. Connective tissue growth factor (CTGF) is regulated by Wnt and bone morphogenetic proteins signaling in osteoblast differentiation of mesenchymal stem cells. J Biol Chem 2004;279 (53):55958-68. [PubMed: 15496414]

139. Alexiewicz JM, Klinger M, Pitts TO, Gaciong Z, Linker-Israeli M, Massry SG. Parathyroid hormone inhibits B cell proliferation: implications in chronic renal failure. J Am Soc Nephrol 1990;1(3):23644. [PubMed: 1966555] 
140. Ma YL, Cain RL, Halladay DL, Yang X, Zeng Q, Miles RR, Chandrasekhar S, Martin TJ, Onyia JE. Catabolic effects of continuous human PTH (1--38) in vivo is associated with sustained stimulation of RANKL and inhibition of osteoprotegerin and gene-associated bone formation. Endocrinology 2001;142(9):4047-54. [PubMed: 11517184]

141. Spencer GJ, Utting JC, Etheridge SL, Arnett TR, Genever PG. Wnt signalling in osteoblasts regulates expression of the receptor activator of NFkappaB ligand and inhibits osteoclastogenesis in vitro. $\mathrm{J}$ Cell Sci 2006;119(Pt 7):1283-96. [PubMed: 16522681]

142. Kimble RB, Srivastava S, Ross FP, Matayoshi A, Pacifici R. Estrogen deficiency increases the ability of stromal cells to support murine osteoclastogenesis via an interleukin- 1and tumor necrosis factormediated stimulation of macrophage colony-stimulating factor production. J Biol Chem 1996;271 (46):28890-7. [PubMed: 8910536]

143. Zaidi M. Skeletal remodeling in health and disease. Nat Med 2007;13(7):791-801. [PubMed: 17618270]

144. Sun L, Peng Y, Sharrow AC, Iqbal J, Zhang Z, Papachristou DJ, Zaidi S, Zhu LL, Yaroslavskiy BB, Zhou H, Zallone A, Sairam MR, Kumar TR, Bo W, Braun J, Cardoso-Landa L, Schaffler MB, Moonga BS, Blair HC, Zaidi M. FSH directly regulates bone mass. Cell 2006;125(2):247-60. [PubMed: 16630814]

145. Manolagas SC. From Estrogen-Centric to Aging and Oxidative Stress: A Revised Perspective of the Pathogenesis of Osteoporosis. Endocr Rev. 2010

146. Nakamura T, Imai Y, Matsumoto T, Sato S, Takeuchi K, Igarashi K, Harada Y, Azuma Y, Krust A, Yamamoto Y, Nishina H, Takeda S, Takayanagi H, Metzger D, Kanno J, Takaoka K, Martin TJ, Chambon P, Kato S. Estrogen prevents bone loss via estrogen receptor alpha and induction of Fas ligand in osteoclasts. Cell 2007;130(5):811-23. [PubMed: 17803905]

147. Krum SA, Miranda-Carboni GA, Hauschka PV, Carroll JS, Lane TF, Freedman LP, Brown M. Estrogen protects bone by inducing Fas ligand in osteoblasts to regulate OC survival. Embo J 2008;27(3):535-45. [PubMed: 18219273]

148. Martin-Millan M, Almeida M, Ambrogini E, Han L, Zhao H, Weinstein RS, Jilka RL, O’Brien CA, Manolagas SC. The estrogen receptor-alpha in osteoclasts mediates the protective effects of estrogens on cancellous but not cortical bone. Mol Endocrinol 2010;24(2):323-34. [PubMed: 20053716]

149. Jilka RL, Takahashi K, Munshi M, Williams DC, Roberson PK, Manolagas SC. Loss of estrogen upregulates osteoblastogenesis in the murine bone marrow. Evidence for autonomy from factors released during bone resorption. J Clin Invest 1998;101(9):1942-50. [PubMed: 9576759]

150. Di Gregorio GB, Yamamoto M, Ali AA, Abe E, Roberson P, Manolagas SC, Jilka RL. Attenuation of the self-renewal of transit-amplifying osteoblast progenitors in the murine bone marrow by 17beta-estradiol. J Clin Invest 2001;107(7):803-812. [PubMed: 11285299]

151. Kousteni S, Bellido T, Plotkin LI, O’Brien CA, Bodenner DL, Han L, Han K, DiGregorio GB, Katzenellenbogen JA, Katzenellenbogen BS, Roberson PK, Weinstein RS, Jilka RL, Manolagas SC. Nongenotropic, sex-nonspecific signaling through the estrogen or androgen receptors: dissociation from transcriptional activity. Cell 2001;104(5):719-30. [PubMed: 11257226]

152. Kousteni S, Han L, Chen JR, Almeida M, Plotkin LI, Bellido T, Manolagas SC. Kinase-mediated regulation of common transcription factors accounts for the bone-protective effects of sex steroids. J Clin Invest 2003;111(11):1651-64. [PubMed: 12782668]

153. Parfitt, AM. Bone remodeling: relationship to the amount and structure of bone, and the pathogenesis and prevention of fractures. In: Riggs, BL., editor. Osteoporosis. 1. Raven Press; New York: 1988. p. 45-93.

154. Parfitt AM. Implications of architecture for the pathogenesis and prevention of vertebral fracture. Bone 1992;13:S41-S47. [PubMed: 1627414]

155. Pacifici R, Brown C, Puscheck E, Friedrich E, Slatopolsky E, Maggio D, McCracken R, Avioli LV. Effect of surgical menopause and estrogen replacement on cytokine release from human blood mononuclear cells. Proc Natl Acad Sci 1991;88:5134-5138. [PubMed: 2052592]

156. Ralston SH, Russell RGG, Gowen M. Estrogen inhibits release of tumor necrosis factor from peripheral blood mononuclear cells in postmenopausal women. J.Bone Miner Res 1990;5:983-988. [PubMed: 2281828] 
157. Shanker G, Sorci-Thomas M, Adams MR. Estrogen modulates the expression of tumor necrosis factor alpha mRNA in phorbol ester-stimulated human monocytic THP-1 cells. Lymphokine Cytokine Res 1994;13:377-382. [PubMed: 7703311]

158. Gao Y, Qian W-P, Dark K, Toraldo G, Lin ASP, Guldberg RE, Flavell RA, Weitzmann MN, Pacifici R. Estrogen prevents bone loss through transforming growth factor $\{$ beta $\}$ signaling in $T$ cells. 2004;101:16618-16623.

159. D’Amelio P, Grimaldi A, Di Bella S, Brianza SZ, Cristofaro MA, Tamone C, Giribaldi G, Ulliers D, Pescarmona GP, Isaia G. Estrogen deficiency increases osteoclastogenesis upregulating T cells activity: a key mechanism in osteoporosis. Bone 2008;43(1):92-100. [PubMed: 18407820]

160. Lee SK, Kadono Y, Okada F, Jacquin C, Koczon-Jaremko B, Gronowicz G, Adams DJ, Aguila HL, Choi Y, Lorenzo JA. T lymphocyte-deficient mice lose trabecular bone mass with ovariectomy. J Bone Miner Res 2006;21(11):1704-12. [PubMed: 17002560]

161. Klein RF, Shea M, Gunness ME, Pelz GB, Belknap JK, Orwoll ES. Phenotypic characterization of mice bred for high and low peak bone mass. J Bone Miner Res 2001;16(1):63-71. [PubMed: 11149491]

162. Brodt MD, Ellis CB, Silva MJ. Growing C57B1/6 mice increase whole bone mechanical properties by increasing geometric and material properties. J Bone Miner Res 1999;14(12):2159-66. [PubMed: 10620076]

163. Richman C, Kutilek S, Miyakoshi N, Srivastava AK, Beamer WG, Donahue LR, Rosen CJ, Wergedal JE, Baylink DJ, Mohan S. Postnatal and pubertal skeletal changes contribute predominantly to the differences in peak bone density between $\mathrm{C} 3 \mathrm{H} / \mathrm{HeJ}$ and C57BL/6J mice. J Bone Miner Res 2001;16 (2):386-97. [PubMed: 11204439]

164. He J, Rosen CJ, Adams DJ, Kream BE. Postnatal growth and bone mass in mice with IGF-I haploinsufficiency. Bone 2006;38(6):826-35. [PubMed: 16427371]

165. Grassi F, Pacifici R. Ovariectomy Increases The Formation Of T Cell Niches At The Resorption Surfaces. J Bone Min Res 2005;20(Suppl. 1) Abs.

166. Adamski J, Ma Z, Nozell S, Benveniste EN. 17beta-Estradiol inhibits class II major histocompatibility complex (MHC) expression: influence on histone modifications and cbp recruitment to the class II MHC promoter. Mol Endocrinol 2004;18(8):1963-74. [PubMed: 15143155]

167. Rammensee HG, Falk K, Rotzschke O. Peptides naturally presented by MHC class I molecules. Annu Rev Immunol 1993;11:213-44. [PubMed: 8476560]

168. Grossman Z, Paul WE. Self-tolerance: context dependent tuning of T cell antigen recognition. Semin Immunol 2000;12(3):197-203. discussion 257-344. [PubMed: 10910740]

169. Tanchot C, Lemonnier FA, Perarnau B, Freitas AA, Rocha B. Differential requirements for survival and proliferation of CD8 naive or memory T cells. Science 1997;276(5321):2057-62. [PubMed: 9197272]

170. Boss JM, Jensen PE. Transcriptional regulation of the MHC class II antigen presentation pathway. Curr Opin Immunol 2003;15(1):105-11. [PubMed: 12495741]

171. Yang NN, Venugopalan M, Hardikar S, Glasebrook A. Identification of an estrogen response element activated by metabolites of 17b-estradiol and raloxifene. Science 1996;273:1222-1225. [PubMed: 8703055]

172. Ryan MR, Shepherd R, Leavey JK, Gao Y, Grassi F, Schnell FJ, Qian WP, Kersh GJ, Weitzmann MN, Pacifici R. An IL-7-dependent rebound in thymic T cell output contributes to the bone loss induced by estrogen deficiency. Proc Natl Acad Sci U S A 2005;102(46):16735-40. [PubMed: 16267136]

173. Lindberg MK, Svensson J, Venken K, Chavoshi T, Andersson N, Moverare Skrtic S, Isaksson O, Vanderschueren D, Carlsten H, Ohlsson C. Liver-derived IGF-I is permissive for ovariectomyinduced trabecular bone loss. Bone 2006;38(1):85-92. [PubMed: 16257281]

174. Lee SK, Kalinowski JF, Jacquin C, Adams DJ, Gronowicz G, Lorenzo JA. Interleukin-7 influences OC function in vivo but is not a critical factor in ovariectomy-induced bone loss. J Bone Miner Res 2006;21(5):695-702. [PubMed: 16734384] 
175. Huang M, Sharma S, Zhu LX, Keane MP, Luo J, Zhang L, Burdick MD, Lin YQ, Dohadwala M, Gardner B, Batra RK, Strieter RM, Dubinett SM. IL-7 inhibits fibroblast TGFbeta production and signaling in pulmonary fibrosis. J Clin Invest 2002;109(7):931-7. [PubMed: 11927620]

176. Dubinett SM, Huang M, Dhanani S, Economou JS, Wang J, Lee P, Sharma S, Dougherty GJ, McBride WH. Down-regulation of murine fibrosarcoma transforming growth factor-beta 1 expression by interleukin 7. J Natl Cancer Inst 1995;87(8):593-7. [PubMed: 7752257]

177. Haynes BF, Sempowski GD, Wells AF, Hale LP. The human thymus during aging. Immunol Res 2000;22(2-3):253-61. [PubMed: 11339360]

178. Douek DC, Koup RA. Evidence for thymic function in the elderly. Vaccine 2000;18(16):1638-41. [PubMed: 10689141]

179. Jamieson BD, Douek DC, Killian S, Hultin LE, Scripture-Adams DD, Giorgi JV, Marelli D, Koup RA, Zack JA. Generation of functional thymocytes in the human adult. Immunity 1999;10(5):56975. [PubMed: 10367902]

180. Steinmann GG, Klaus B, Muller-Hermelink HK. The involution of the ageing human thymic epithelium is independent of puberty. A morphometric study. Scand J Immunol 1985;22(5):56375. [PubMed: 4081647]

181. Hakim FT, Memon SA, Cepeda R, Jones EC, Chow CK, Kasten-Sportes C, Odom J, Vance BA, Christensen BL, Mackall CL, Gress RE. Age-dependent incidence, time course, and consequences of thymic renewal in adults. J Clin Invest 2005;115(4):930-9. [PubMed: 15776111]

182. Mackall CL, Fry TJ, Bare C, Morgan P, Galbraith A, Gress RE. IL-7 increases both thymicdependent and thymic-independent $\mathrm{T}$-cell regeneration after bone marrow transplantation. Blood 2001;97(5):1491-7. [PubMed: 11222398]

183. Chu YW, Memon SA, Sharrow SO, Hakim FT, Eckhaus M, Lucas PJ, Gress RE. Exogenous IL-7 increases recent thymic emigrants in peripheral lymphoid tissue without enhanced thymic function. Blood 2004;104(4):1110-9. [PubMed: 15130942]

184. Alpdogan O, Schmaltz C, Muriglan SJ, Kappel BJ, Perales MA, Rotolo JA, Halm JA, Rich BE, van den Brink MR. Administration of interleukin-7 after allogeneic bone marrow transplantation improves immune reconstitution without aggravating graft-versus-host disease. Blood 2001;98(7): 2256-65. [PubMed: 11568014]

185. Utsuyama M, Hirokawa K. Hypertrophy of the thymus and restoration of immune functions in mice and rats by gonadectomy. Mech Ageing Dev 1989;47(3):175-85. [PubMed: 2785623]

186. Perisic M, Arsenovic-Ranin N, Pilipovic I, Kosec D, Pesic V, Radojevic K, Leposavic G. Role of ovarian hormones in age-associated thymic involution revisited. Immunobiology 215(4):275-93. [PubMed: 19577818]

187. Okasha SA, Ryu S, Do Y, McKallip RJ, Nagarkatti M, Nagarkatti PS. Evidence for estradiol-induced apoptosis and dysregulated T cell maturation in the thymus. Toxicology 2001;163(1):49-62. [PubMed: 11376864]

188. Roden AC, Moser MT, Tri SD, Mercader M, Kuntz SM, Dong H, Hurwitz AA, McKean DJ, Celis E, Leibovich BC, Allison JP, Kwon ED. Augmentation of T cell levels and responses induced by androgen deprivation. J Immunol 2004;173(10):6098-108. [PubMed: 15528346]

189. Sutherland JS, Goldberg GL, Hammett MV, Uldrich AP, Berzins SP, Heng TS, Blazar BR, Millar JL, Malin MA, Chidgey AP, Boyd RL. Activation of Thymic Regeneration in Mice and Humans following Androgen Blockade. J Immunol 2005;175(4):2741-53. [PubMed: 16081852]

190. Hreshchyshyn MM, Hopkins A, Zylstra S, Anbar M. Effects of natural menopause, hysterectomy, and oophorectomy on lumbar spine and femoral neck bone densities. Obstet Gynecol 1988;72(4): 631-8. [PubMed: 3419740]

191. Basu S, Michaelsson K, Olofsson H, Johansson S, Melhus H. Association between oxidative stress and bone mineral density. Biochem Biophys Res Commun 2001;288(1):275-9. [PubMed: 11594785]

192. Maggio D, Barabani M, Pierandrei M, Polidori MC, Catani M, Mecocci P, Senin U, Pacifici R, Cherubini A. Marked decrease in plasma antioxidants in aged osteoporotic women: results of a cross-sectional study. J Clin Endocrinol Metab 2003;88(4):1523-7. [PubMed: 12679433] 
193. Muthusami S, Ramachandran I, Muthusamy B, Vasudevan G, Prabhu V, Subramaniam V, Jagadeesan A, Narasimhan S. Ovariectomy induces oxidative stress and impairs bone antioxidant system in adult rats. Clin Chim Acta 2005;360(1-2):81-6. [PubMed: 15970279]

194. Lean JM, Davies JT, Fuller K, Jagger CJ, Kirstein B, Partington GA, Urry ZL, Chambers TJ. A crucial role for thiol antioxidants in estrogen-deficiency bone loss. J Clin Invest 2003;112(6):91523. [PubMed: 12975476]

195. Wimalawansa SJ, De Marco G, Gangula P, Yallampalli C. Nitric oxide donor alleviates ovariectomyinduced bone loss. Bone 1996;18(4):301-4. [PubMed: 8726385]

196. Hao YJ, Tang Y, Chen FB, Pei FX. Different doses of nitric oxide donor prevent osteoporosis in ovariectomized rats. Clin Orthop Relat Res 2005;(435):226-31. [PubMed: 15930943]

197. Jamal SA, Cummings SR, Hawker GA. Isosorbide mononitrate increases bone formation and decreases bone resorption in postmenopausal women: a randomized trial. J Bone Miner Res 2004;19 (9):1512-7. [PubMed: 15312252]

198. Steinbeck MJ, Appel WH Jr, Verhoeven AJ, Karnovsky MJ. NADPH-oxidase expression and in situ production of superoxide by osteoclasts actively resorbing bone. J Cell Biol 1994;126(3):76572. [PubMed: 8045939]

199. Ha H, Kwak HB, Lee SW, Jin HM, Kim HM, Kim HH, Lee ZH. Reactive oxygen species mediate RANK signaling in osteoclasts. Exp Cell Res 2004;301(2):119-27. [PubMed: 15530848]

200. Lean JM, Jagger CJ, Kirstein B, Fuller K, Chambers TJ. Hydrogen peroxide is essential for estrogendeficiency bone loss and OC formation. Endocrinology 2005;146(2):728-35. [PubMed: 15528306]

201. Reth M. Hydrogen peroxide as second messenger in lymphocyte activation. Nat Immunol 2002;3 (12):1129-34. [PubMed: 12447370]

202. Lean J, Kirstein B, Urry Z, Chambers T, Fuller K. Thioredoxin-1 mediates OC stimulation by reactive oxygen species. Biochem Biophys Res Commun 2004;321(4):845-50. [PubMed: 15358104]

203. Chen JR, Plotkin LI, Aguirre JI, Han L, Jilka RL, Kousteni S, Bellido T, Manolagas SC. Transient versus sustained phosphorylation and nuclear accumulation of ERKs underlie anti-versus proapoptotic effects of estrogens. J Biol Chem 2005;280(6):4632-8. [PubMed: 15557324]

204. Jagger CJ, Lean JM, Davies JT, Chambers TJ. Tumor necrosis factor-alpha mediates osteopenia caused by depletion of antioxidants. Endocrinology 2005;146(1):113-8. [PubMed: 15388652]

205. Mizuashi M, Ohtani T, Nakagawa S, Aiba S. Redox imbalance induced by contact sensitizers triggers the maturation of dendritic cells. J Invest Dermatol 2005;124(3):579-86. [PubMed: 15737199]

206. Rutault K, Alderman C, Chain BM, Katz DR. Reactive oxygen species activate human peripheral blood dendritic cells. Free Radic Biol Med 1999;26(1-2):232-8. [PubMed: 9890657]

207. Maemura K, Zheng Q, Wada T, Ozaki M, Takao S, Aikou T, Bulkley GB, Klein AS, Sun Z. Reactive oxygen species are essential mediators in antigen presentation by Kupffer cells. Immunol Cell Biol 2005;83(4):336-43. [PubMed: 16033528]

208. Vosters O, Neve J, De Wit D, Willems F, Goldman M, Verhasselt V. Dendritic cells exposed to nacystelyn are refractory to maturation and promote the emergence of alloreactive regulatory t cells. Transplantation 2003;75(3):383-9. [PubMed: 12589163]

209. Verhasselt V, Vanden Berghe W, Vanderheyde N, Willems F, Haegeman G, Goldman M. N-acetylL-cysteine inhibits primary human $\mathrm{T}$ cell responses at the dendritic cell level: association with NFkappaB inhibition. J Immunol 1999;162(5):2569-74. [PubMed: 10072497]

210. Matsue H, Edelbaum D, Shalhevet D, Mizumoto N, Yang C, Mummert ME, Oeda J, Masayasu H, Takashima A. Generation and function of reactive oxygen species in dendritic cells during antigen presentation. J Immunol 2003;171(6):3010-8. [PubMed: 12960326]

211. Hildeman DA, Mitchell T, Teague TK, Henson P, Day BJ, Kappler J, Marrack PC. Reactive oxygen species regulate activation-induced T cell apoptosis. Immunity 1999;10(6):735-44. [PubMed: 10403648]

212. Finkel T. Oxidant signals and oxidative stress. Curr Opin Cell Biol 2003;15(2):247-54. [PubMed: 12648682]

213. Ozaki M, Suzuki S, Irani K. Redox factor-1/APE suppresses oxidative stress by inhibiting the rac1 GTPase. Faseb J 2002;16(8):889-90. [PubMed: 12039869] 
214. Almeida M, Ambrogini E, Han L, Manolagas SC, Jilka RL. Increased lipid oxidation causes oxidative stress, increased peroxisome proliferator-activated receptor-gamma expression, and diminished pro-osteogenic Wnt signaling in the skeleton. J Biol Chem 2009;284(40):27438-48. [PubMed: 19657144]

215. Almeida M, Han L, Martin-Millan M, Plotkin LI, Stewart SA, Roberson PK, Kousteni S, O’Brien CA, Bellido T, Parfitt AM, Weinstein RS, Jilka RL, Manolagas SC. Skeletal involution by ageassociated oxidative stress and its acceleration by loss of sex steroids. J Biol Chem 2007;282(37): 27285-97. [PubMed: 17623659]

216. Almeida M, Martin-Millan M, Ambrogini E, Bradsher R, Han L, Chen XD, Roberson PK, Weinstein RS, O'Brien CA, Jilka RL, Manolagas SC. Estrogens Attenuate Oxidative Stress and the Differentiation and Apoptosis of Osteoblasts by DNA Binding-Independent Actions of the ERalpha. J Bone Miner Res. 2009

217. Fox HS, Bond BL, Parslow TG. Estrogen regulates the IFN-gamma promoter. J Immunol 1991;146 (12):4362-7. [PubMed: 1904081] 

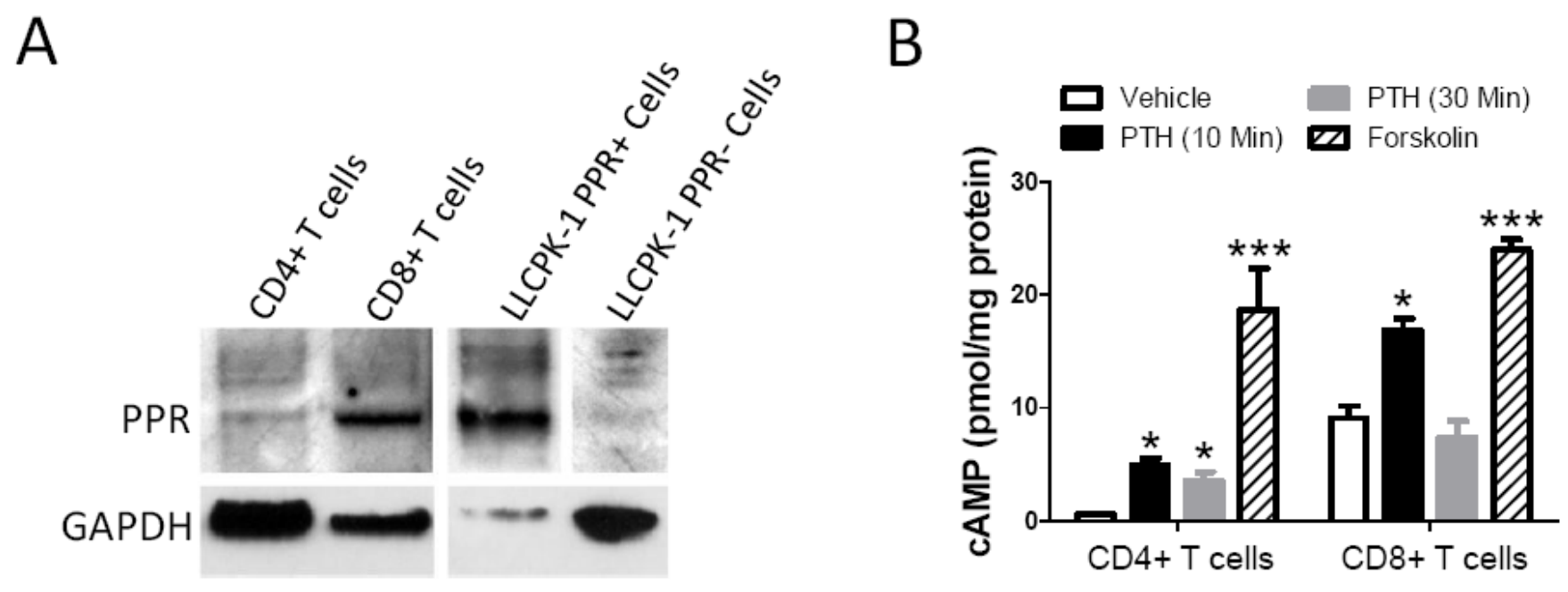

Figure 1.

T cells express functional PTHR1 (PPR) receptors. A Measurement of PPR expression by Western blotting in spleen CD4+ and CD8+ T cells from intact mice. PPR-negative LLCPK-1 cells stably transfected with empty vector (LLCPK-1 PPR-) or PPR expression vector (LLCPK-1 PPR + ) are negative and positive controls, respectively. B Effect (mean \pm SEM) of in vitro PTH treatment $(50 \mathrm{nM})$ on the production of cAMP by spleen CD4+ and CD8+ T cells from intact mice. Forskolin was used as a positive control. $*=p<0.05$, $* * *=p<0.001$ as compared to the corresponding vehicle. 

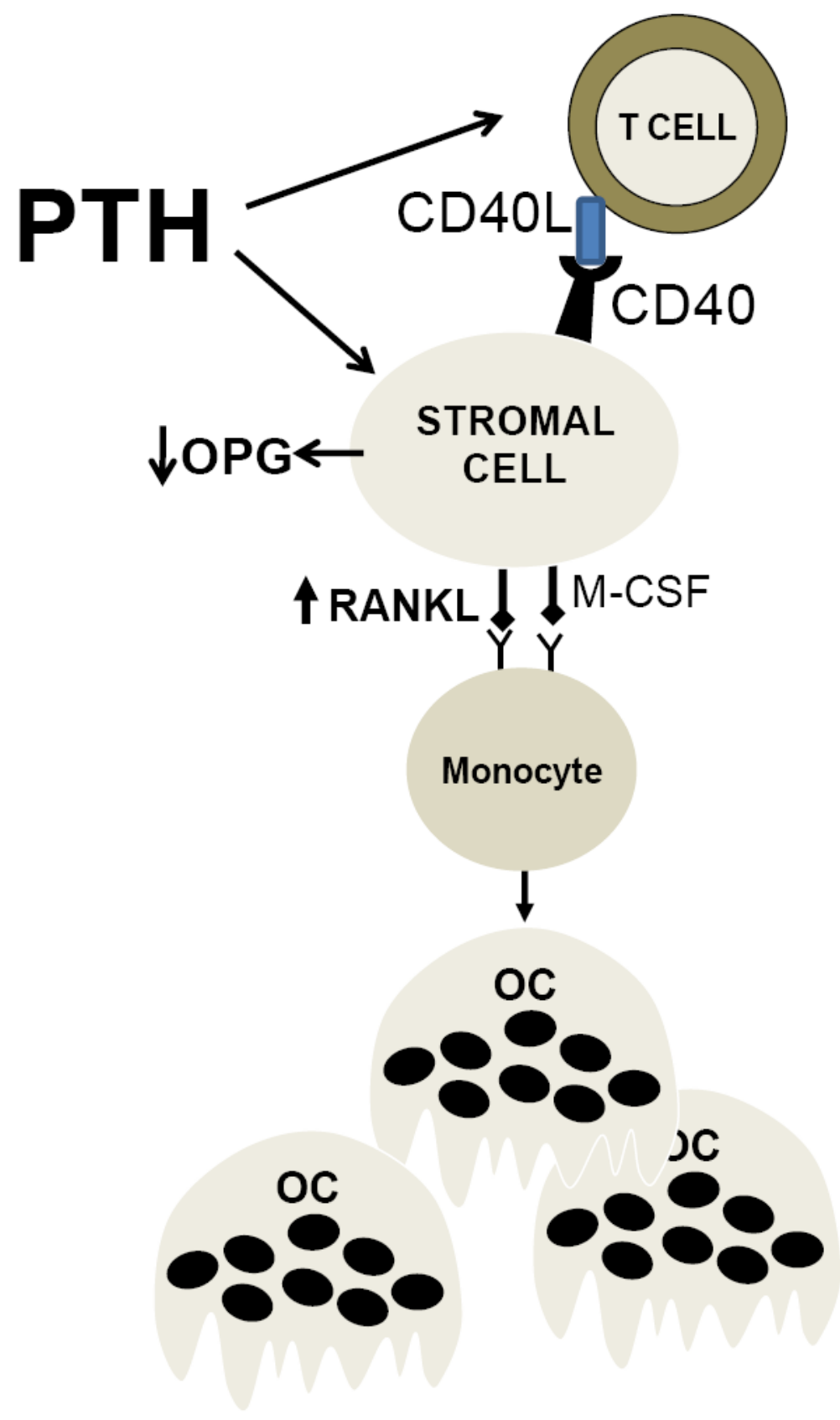

Figure 2.

Schematic representation of the role of T cells in the mechanism by which continuous PTH stimulates OC formation. T cell expressed CD40L stimulates CD40 signaling in SCs and their osteoblastic progeny. CD40L/CD40 signaling increases SC proliferation and decreases SC apoptosis. Together these effects expand the pool of osteoclastogenic SCs in the BM (not shown). Furthermore, CD40L/CD40 signaling increases the osteoclastogenic activity of SCs by augmenting the SC production of RANKL and blunting their secretion of OPG. The result is a potentiation of the capacity of PTH to stimulate the formation of OCs. 


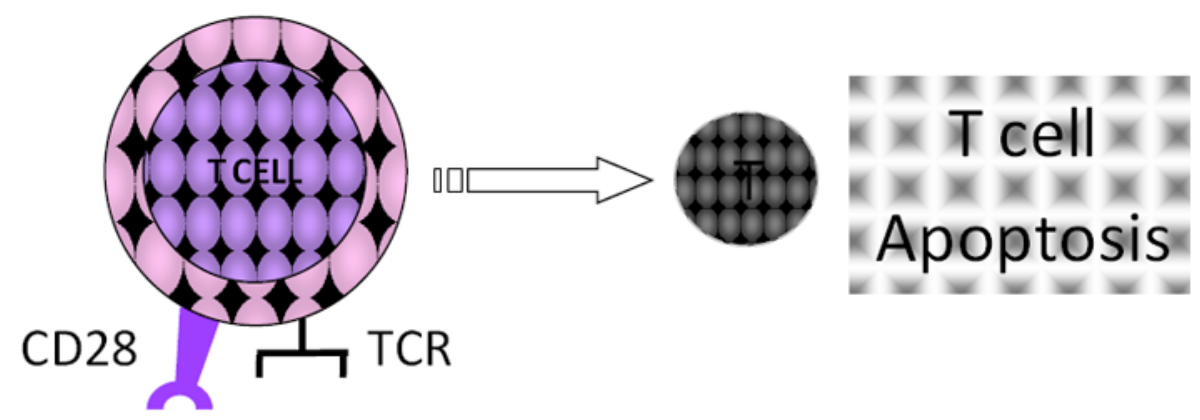

\section{CTLA-4 Ig}
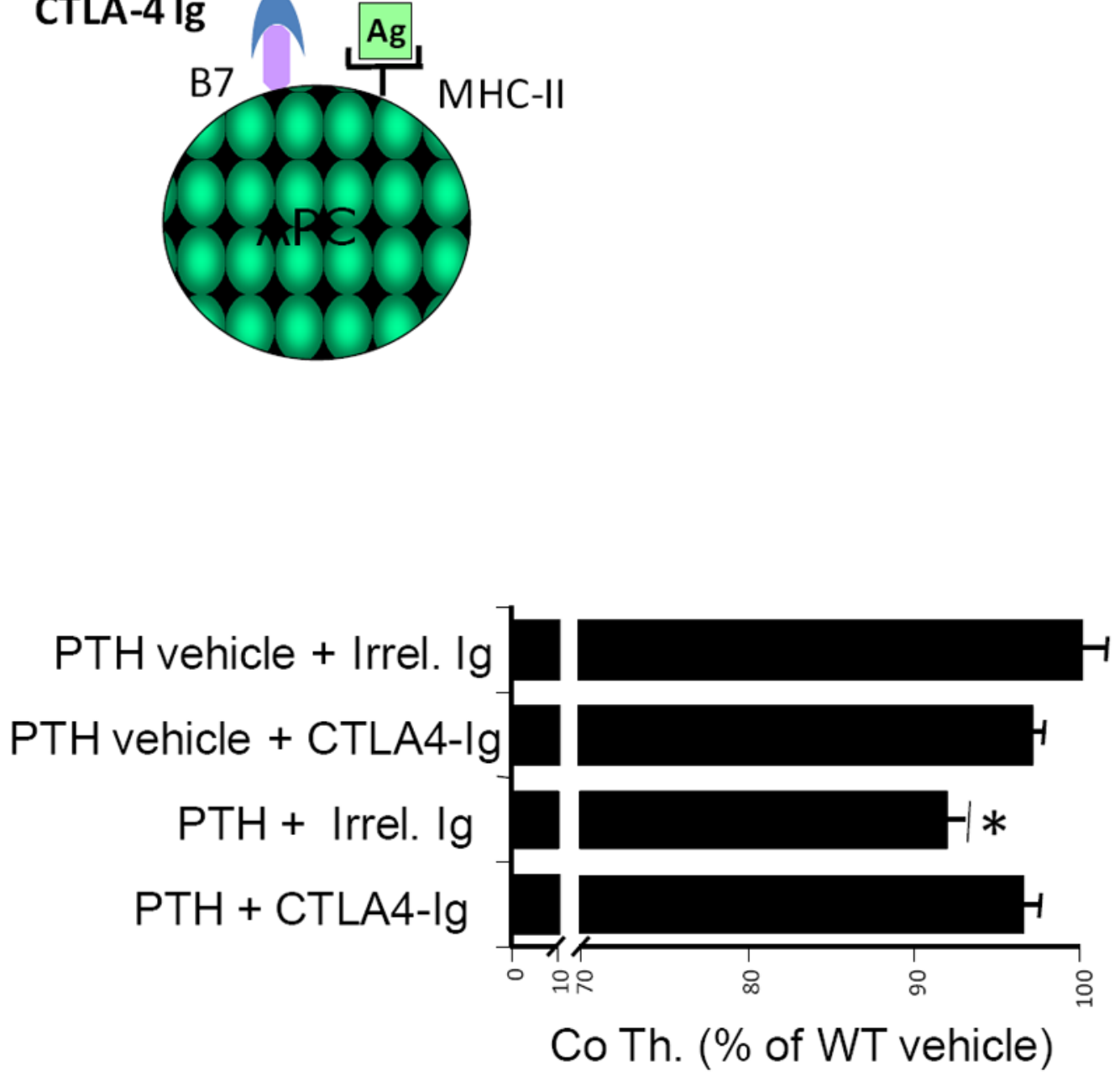

Figure 3.

Treatment with CTLA-4 Ig blocks the loss of cortical bone induced by continuous PTH treatment. The upper panel shows a schematic representation of the mechanism of action of CTLA-4 Ig. Antigen presenting cells (APCs) carry antigenic peptides bound to MHC-II molecules which stimulate the T cell receptor (TCR). In physiologic condition the costimulatory receptor B7 expressed on APCs binds to CD28 on T cells. The simultaneous engagement of TCR and CD28 by the appropriate counter receptors results in T cell activation. CTLA-4 Ig binds to B7 preventing the stimulation of CD28. Engagement of TCR by antigenic peptides in the absence of CD28 stimulation results in T cell anergy and T cell apoptosis. 
The bottom panel shows trabecular cortical thickness as measured by $\mu \mathrm{CT}$. WT mice were injected with either CTLA-4 Ig (100 $\mu \mathrm{g}$ IP 3 times a week) or irrelevant Ig for one week. Mice were also infused continuously for 2 weeks with either PTH ( $80 \mu \mathrm{g} / \mathrm{kg} / \mathrm{day})$ or vehicle using osmotic pumps, staring 3 days after the first CTLA-4 Ig injection. Femurs were harvested at sacrifice and analyzed by $\mu \mathrm{CT} . *=p<0.05$, compared to the other groups. 


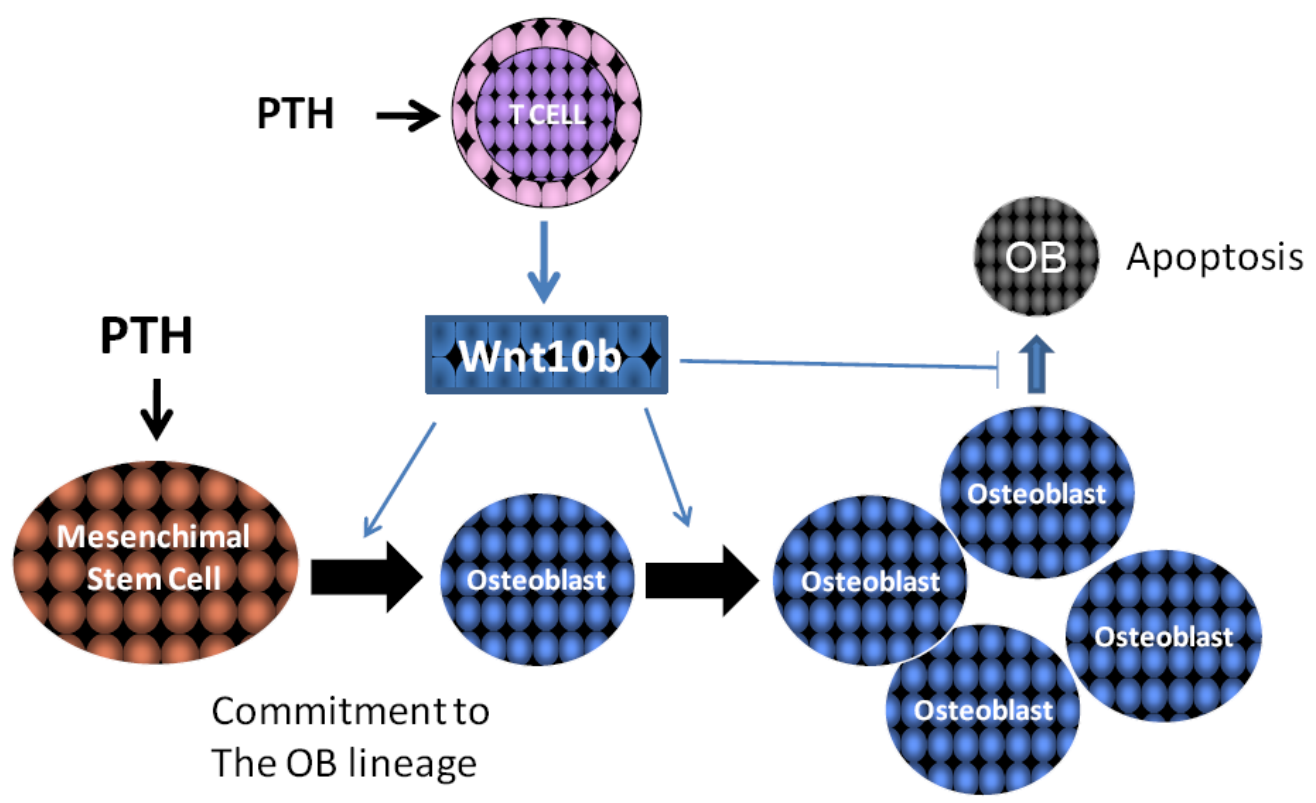

Proliferation and differentiation

Figure 4.

Schematic representation of the role of T cells in the mechanism by which intermittent PTH treatment stimulates bone formation. In response to PTH stimulation BM T cells secrete the Wnt ligand Wnt10b. Upon binding to LRP4/5/6 receptors on SCs and OBs, Wnt $10 \mathrm{~b}$ activates Wnt signaling, which in turn increases the commitment of SCs to the osteoblastic lineage, stimulates $\mathrm{OB}$ proliferation and differentiation, and decreases $\mathrm{OB}$ apoptosis. The net result of Wnt 10b driven Wnt activation is an increase in the number and the lifespan of mature OBs. 

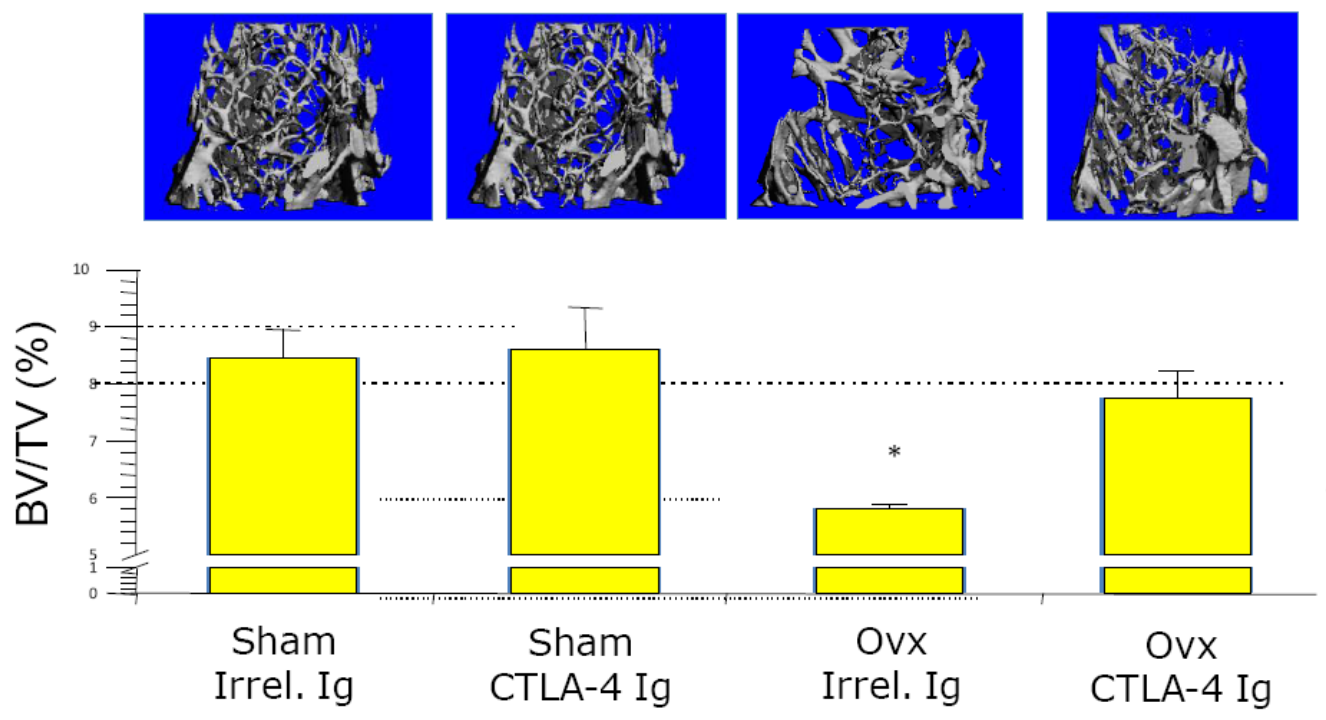

Figure 5.

Treatment with CTLA4-Ig prevents ovx induced bone loss. The figure shows trabecular BV/ TV as measured by $\mu \mathrm{CT}$ at sacrifice. Ovx and sham operated mice were treated with CTLA4Ig $(500 \mathrm{mg} /$ mouse $)$ or Isotype-matched Irrelevant Ig (Irr-Ig) $(500 \mathrm{mg} / \mathrm{mouse}) 3$ times $\times$ week for 2 weeks and then sacrificed. $* \mathrm{p}<0.05$ compared to Irrelevant Ig treated shams. 